\title{
DISCLAIMER
}

This report was prepared as an account of work sponsored by an agency of the United States Government. Neither the United States Government nor any agency thereof, nor any of their employees, makes any warranty, express or implied, or assumes any legal liability or responsibility for the accuracy, completeness, or usefulness of any information, apparatus, product, or process disclosed, or represents that its use would not infringe privately owned rights. Reference herein to any specific commercial product, process, or service by trade name, trademark, manufacturer, or otherwise does not necessarily constitute or imply its endorsement, recommendation, or favoring by the United States Government or any agency thereof. The views and opinions of authors expressed herein do not necessarily state or reflect those of the United States Government or any agency thereof.

BNL-61503

Informal Report

\section{Sorption of Radioactive Contaminants by Sediment from the Kara Sea}

\author{
Mark Fuhrmann ${ }^{1}$, Huan Zhou ${ }^{2}$, James Neiheisel ${ }^{3}$ and Robert Dyer ${ }^{3}$
}

February 1, 1995

Environmental and Waste Technology Center

Brookhaven National Laboratory

Upton, NY 11973-5000

\author{
Submitted to the U.S. Environmental Protection Agency \\ Office of Radiation and Indoor Air \\ Washington, D.C., 20460
}

1. Brookhaven National Laboratory

2. Visiting Scientist, Brookhaven National Laboratory

3. U.S. Environmental Protection Agency 
$\because$ 


\section{DISCLAIMER}

Portions of this document may be illegible in electronic image products. Images are produced from the best available original document. 


\begin{abstract}
The purpose of this study is to quantify some of the parameters needed to perform nearfield modeling of sites in the Kara Sea that were impacted by the disposal of radioactive waste. The parameters of interest are: the distribution coefficients $\left(\mathrm{K}_{\mathrm{d}}\right)$ for several important radionuclides, the mineralogy of the sediment, and the relationship of $\mathrm{K}_{d}$ to liquid to solid ratio.

Sediment from the Kara Sea (location: $73^{\circ} 00^{\prime} \mathrm{N}, 58^{\circ} 00^{\prime} \mathrm{E}$ ) was sampled from a depth of 287 meters on August 23/24, 1992, during a joint Russian/Norwegian scientific cruise. Analysis of the material included mineralogy, grain size and total organic carbon. Uptake kinetics were determined for ${ }^{85} \mathrm{Sr},{ }^{99} \mathrm{Tc},{ }^{125} \mathrm{I},{ }^{137} \mathrm{Cs},{ }^{210} \mathrm{~Pb},{ }^{232} \mathrm{U}$, and ${ }^{241} \mathrm{Am}$ and distribution coefficients $\left(\mathrm{K}_{\mathcal{d}}\right)$ were determined for these radionuclides using batch type experiments. Sorption isotherms were developed for ${ }^{85} \mathrm{Sr}$, ${ }^{99} \mathrm{Tc}$, and ${ }^{137} \mathrm{Cs}$ to examine the effect that varying the concentration of a tracer has on the quantity of that tracer taken up by the solid. The effect of liquid to solid ratio on the uptake of contaminants was determined for ${ }^{99} \mathrm{Tc}$ and ${ }^{137} \mathrm{Cs}$. In another set of experiments, the sediment was separated into four size fractions and uptake was determined for each fraction for ${ }^{85} \mathrm{Sr},{ }^{99} \mathrm{Tc}$, and ${ }^{137} \mathrm{Cs}$. In addition, the sediment was analyzed to determine if it contains observable concentrations of anthropogenic radionuclides.
\end{abstract}


TABLE OF CONTENTS

Page

ABSTRACT $\ldots \ldots \ldots \ldots \ldots \ldots \ldots \ldots \ldots \ldots \ldots \ldots \ldots \ldots \ldots \ldots$ ii

EXECUTIVE SUMMARY $\ldots \ldots \ldots \ldots \ldots \ldots \ldots \ldots \ldots \ldots \ldots$

ACKNOWLEDGEMENTS $\ldots \ldots \ldots \ldots \ldots \ldots \ldots \ldots \ldots \ldots$ xi

1. INTRODUCTION $\ldots \ldots \ldots \ldots \ldots \ldots \ldots \ldots \ldots \ldots \ldots \ldots \ldots \ldots$

2. MINERALOGY AND OTHER SEDIMENT PARAMETERS $\ldots \ldots \ldots \ldots \ldots$

3. SORPTION KINETICS $\ldots \ldots \ldots \ldots \ldots \ldots \ldots \ldots \ldots \ldots$

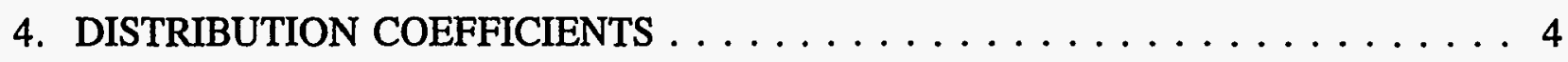

5. SORPTION AS A FUNCTION OF LIQUID TO SOLID RATIO . . . . . . . . 27

6. SORPTION ON DIFFERENT SIZE FRACTIONS OF THE SEDIMENT . . . . . 33

7. RADIONUCLIDES ON THE SEDIMENT . . . . . . . . . . . . 39

8. CONCLUSIONS $\ldots \ldots \ldots \ldots \ldots \ldots \ldots \ldots \ldots \ldots$

REFERENCES ........................ 46 


\section{LIST OF FIGURES}

Page

Figure 1 The Kara Sea near Novaya Zemlya, showing the location from which the sediment sample was taken $\ldots \ldots \ldots \ldots \ldots$

Figure 2 The sediment core after sectioning ............... 6

Figure 3 Sorption kinetics of lead on Kara Sea sediment, steady state uptake took about 50 hours . . . . . . . . . . . . . . . . . 10

Figure 4 Sorption kinetics of uranium on Kara Sea sediment, the time to steady state was more than 350 hours $\ldots \ldots \ldots \ldots \ldots \ldots 11$

Figure 5 Sorption kinetics of iodine on Kara Sea sediment . . . . . . . . 12

Figure 6 Sorption kinetics of technetium on sediment from the Kara Sea . . . . . . 13

Figure 7 Sorption kinetics of cesium on sediment from the Kara Sea . . . . . . . 14

Figure $8 \quad$ Sorption kinetics of strontium on Kara Sea sediment . . . . . . . . . . 15

Figure 9 The isotherm for Cs-137. Also shown are the points for the

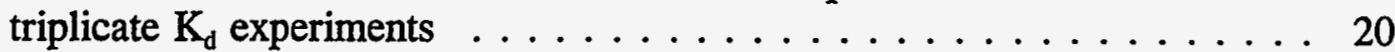

Figure 10 The quantity of ${ }^{137} \mathrm{Cs}$ sorbed per gram of sediment as a function of the starting activity of ${ }^{137} \mathrm{Cs}$ in the contact solution . . . . . . . 21

Figure 11 The isotherm for ${ }^{85} \mathrm{Sr}$, showing that with the exception of one point all data, including that from the triplicate batch experiments,

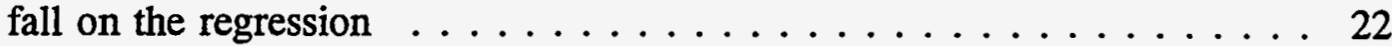

Figure 12 The quantity of ${ }^{85} \mathrm{Sr}$ sorbed per gram of sediment as a function of the starting activity of ${ }^{85} \mathrm{Sr}$ in the contact solution . . . . . . . . 23

Figure 13 The isotherm for ${ }^{99} \mathrm{Tc}$ is shown along with data from the triplicate batch experiment . . . . . . . . . . . . . . . 24

Figure 14 The $\mathrm{K}_{d}$ values of ${ }^{99} \mathrm{Tc}$ plotted as a function of the starting activity of ${ }^{99} \mathrm{Tc}$ in the contact solution, illustrating the difference between the $K_{d}$ 's of the two experiments . . . . . . . . . . . 25

Figure 15 Plotting the activity in solution as a function of the quantity of tracer added gives a determination of the background counts that develop after the contact solution is exposed to the sediment . . . . . . 26

Figure 16 Several scenarios are illustrated for the release of radioactive liquid from a waste container . . . . . . . . . . . . . . 28

Figure 17 The relationship between the uptake of ${ }^{137} \mathrm{Cs}$ and the liquid to solid ratio is linear with a slope of 204 and $R^{2}$ of 0.999 . . . . . . . . . . 29

Figure 18 The relationship between the uptake of ${ }^{99} \mathrm{Tc}$ and the liquid to solid ratio is linear . . . . . . . . . . . . . . . . . 30

Figure $19 \quad \mathrm{~K}_{\mathrm{d}}$ values determined for ${ }^{137} \mathrm{Cs}$ and ${ }^{99} \mathrm{Tc}$ are affected differently by changing the liquid to solid ratio $\ldots \ldots \ldots \ldots \ldots \ldots$

Figure 20a The percentage of ${ }^{137} \mathrm{Cs}$ sorbed on each of four size fractions is shown on the histogram . . . . . . . . . . . . . 34

Figure $20 \mathrm{~b} \quad \mathrm{~K}_{\mathrm{d}}$ values for ${ }^{137} \mathrm{Cs}$ were determined for each of the four size fractions . . 34

Figure 21a The percentage of ${ }^{99} \mathrm{Tc}$ sorbed on each of four size fractions is shown on the histogram $\ldots \ldots \ldots \ldots \ldots \ldots \ldots \ldots \ldots$ 


\section{LIST OF FIGURES (cont.)}

Page

Figure $21 \mathrm{~b} \quad \mathrm{~K}_{\mathrm{d}}$ values for ${ }^{99} \mathrm{Tc}$ were determined for each of the four size fractions, with the finest fraction having a significantly higher $\mathrm{K}_{\mathrm{d}} \ldots \ldots \ldots 35$

Figure 22a The percentage of ${ }^{85} \mathrm{Sr}$ sorbed on each of four size fractions is shown on the histogram . . . . . . . . . . . . . . 36

Figure $22 b \quad \mathrm{~K}_{d}$ values for ${ }^{85} \mathrm{Sr}$ were determined for each of the four size fractions, with the two intermediate size fractions having higher $K_{d}$ values $\ldots \ldots 36$

\section{LIST OF TABLES}

\section{$\underline{\text { Page }}$}

Table 1 Mineral Composition of Sediment Sample, Kara Sea, Station $2 \ldots \ldots$. . . . 7

Table 2 Average Composition of Heavy Mineral Suite Kara Sea Sediment Sample, Station $2 \ldots \ldots \ldots \ldots \ldots \ldots \ldots$

Table 3 Kinetics and Average $\mathrm{K}_{\mathrm{d}}$ Values . . . . . . . . . . . . . . . . 9

Table $4 \quad K_{D}$ Values for Radionuclides on Kara Sea Sediment . . . . . . . . . . . . 16

Table 5 Isotherm Data for Cs, $\mathrm{Sr}$ and $\mathrm{Tc} \ldots \ldots \ldots \ldots \ldots \ldots$

Table 6 Effect of Grain Size $\mathrm{On} \mathrm{Kd}$ for $\mathrm{Cs}, \mathrm{Tc}$ and $\mathrm{Sr} \ldots \ldots \ldots \ldots$

Table 7 Depth and Weights of Specimens for Radiochemical Analysis . . . . . . . . 41

Table 8 Radionuclide Analysis of Sediment From the Kara Sea . . . . . . . . . . . 42

Table 9 Plutonium - 239/240 Activity in a Sediment Sample From the Kara Sea . . . 43 


\section{EXECUTIVE SUMMARY}

The purpose of this study is to quantify some of the parameters needed to perform nearfield modeling of sites in the Kara Sea that were impacted by the disposal of radioactive waste. The parameters of interest are: the distribution coefficients $\left(\mathrm{K}_{\mathrm{d}}\right)$ of major contaminant radionuclides, the mineralogy of the sediment, and the relationship of $K_{d}$ to liquid to solid ratio. The distribution coefficient, $K_{d}$ is the ratio, at steady-state, of the concentration on the sediment to the concentration in the water. It is a critical parameter that describes the degree to which a sediment will retain or immobilize a contaminant.

Sediment from the Kara Sea (location: $73^{\circ} 00^{\prime} \mathrm{N}, 58^{\circ} 00^{\prime}$ E) was sampled from a depth of 287 meters on August 23/24, 1992 and was provided by the Norwegian Radiation Protection Authority, Oslo, Norway. The sediment was a suboxic mud with an average grain size of 17 $\mu \mathrm{m}(71.5 \%$ silt and $21 \%$ clay) and Total Organic Carbon of $93 \mathrm{mg} / \mathrm{g}$. The clay fraction was composed primarily of mixed layer smectite $(34 \%)$, illite $(18 \%)$, chlorite $(17 \%)$ and kaolinite (14\%). Uptake kinetics were determined for ${ }^{85} \mathrm{Sr},{ }^{99} \mathrm{Tc},{ }^{125} \mathrm{I},{ }^{137} \mathrm{Cs},{ }^{210} \mathrm{~Pb},{ }^{232} \mathrm{U}$, and ${ }^{241} \mathrm{Am}$. Slow kinetics were observed for uranium and technetium implying that the rate limiting process was probably not adsorption but a reaction prior to uptake. Distribution coefficients were determined for these radionuclides using batch type experiments. In addition the $\mathrm{K}_{\mathrm{d}}$ values for ${ }^{85} \mathrm{Sr},{ }^{99} \mathrm{Tc}$, and ${ }^{137} \mathrm{Cs}$ were also determined using isotherms, allowing an evaluation of the relationship between sorption and concentrations of contaminant. If the relationship is linear at the relatively high tracer concentrations in the laboratory experiments, then it is appropriate to use that $\mathrm{K}_{\mathrm{d}}$ for the much lower concentrations typically found in the environment. The isotherms for ${ }^{85} \mathrm{Sr},{ }^{99} \mathrm{Tc}$, and ${ }^{137} \mathrm{Cs}$ were linear. For the batch tests and the isotherms the $\mathrm{K}_{d}$ values were:

\begin{tabular}{|c|c|}
\hline Uranium & $\begin{array}{l}\text { Slow Kinetics } \\
\mathrm{K}_{\mathrm{d}}=23 \mathrm{~mL} / \mathrm{g} \text { (batch) }\end{array}$ \\
\hline Lead & $\begin{array}{l}\text { Rapid Kinetics } \\
\text { All Pb Removed From Solution (batch) }\end{array}$ \\
\hline Cesium & $\begin{array}{l}\text { Rapid Kinetics } \\
\mathrm{K}_{\mathrm{d}} \text { varies with Solid:Liquid, } \\
\mathrm{K}_{\mathrm{d}}=230 \text { (batch), } \mathrm{K}_{\mathrm{d}}=360 \text { (isotherm }\end{array}$ \\
\hline Strontium & $\begin{array}{l}\text { Rapid Kinetics } \\
\mathrm{K}_{\mathrm{d}}=5.3 \text { (batch), } \mathrm{K}_{\mathrm{d}}=3.2 \text { (isotherm) }\end{array}$ \\
\hline Iodine & $\begin{array}{l}\text { Slow Kinetics } \\
\mathrm{K}_{\mathrm{d}}=56 \text { (batch) }\end{array}$ \\
\hline
\end{tabular}

Technetium Slow Kinetics

$$
K_{d}=43 \text { (batch), } K_{d}=3.9 \text { (isotherm) }
$$


Americium Very Rapid Kinetics

$$
\mathrm{K}_{\mathrm{d}}=5600 \text { or greater (batch) }
$$

The $\mathrm{K}_{\mathrm{d}}$ values of ${ }^{99} \mathrm{Tc}$ and ${ }^{137} \mathrm{Cs}$ are influenced by the solid to liquid ratio. While in a clean laboratory experiment with simple materials there should be no effect; in a natural system (or at least using natural materials) we observed that the $\mathrm{K}_{\mathrm{d}}$ for ${ }^{137} \mathrm{Cs}$ varied nonlinearly from 40 to $3600 \mathrm{~mL} / \mathrm{g}$ as the liquid to solid ratio varied from 3.4 to 6400 . The sediment was separated into four size fractions and uptake was determined for each fraction for ${ }^{137} \mathrm{Cs},{ }^{85} \mathrm{Sr}$ and ${ }^{99} \mathrm{Tc}$. Overall there is relatively little difference, if any, in sorption among the three finer grained fractions. The coarsest fraction did have significantly lower uptake for all three tracers, as one would expect. In comparing the $\mathrm{K}_{\mathrm{d}}$ values obtained for this set of experiments with the values obtained in the batch and isotherm experiments, there are large differences, with the values from this experiment being much higher. The likely explanation for this effect is that the grain size separation process resulted in desorption of trace metals and deflocculation of mineral grains giving the sediment greater surface area and capacity to sorb contaminants than would likely be found in the natural environment.

Analysis for anthropogenic radionuclides indicated the presence only of ${ }^{239 / 240} \mathrm{Pu}$ in the sediment with the highest activity, at the top section of the core, being $0.420 \mathrm{~Bq} / \mathrm{Kg}$. Other anthropogenic radionuclides including the beta-emitter ${ }^{90} \mathrm{Sr}$ and the gamma-emitters such as ${ }^{60} \mathrm{Co}$, ${ }^{134} \mathrm{Cs}$ and ${ }^{137} \mathrm{Cs}$ were below detection limits. 


\section{ACKNOWLEDGEMENTS}

This work was funded by the United States Department of State.

The authors would like to thank the following:

- Darryl Keith of the Environmental Protection Agency (EPA), Environmental Research Laboratory, Narragansett, Rhode Island for grain size and TOC analysis,

- the United States Corps of Engineers Laboratory in Marietta, Georgia for use of their facilities for mineralogical analysis,

- and Professor Nicholas Fisher of the Marine Sciences Research Center and Professor Martin Schoonen of the Department of Earth and Spaces Sciences, both at the State University of New York at Stony Brook, for their helpful comments. 


\section{INTRODUCTION}

Large quantities of radioactive materials have been disposed of either directly into the Kara Sea or in nearby terrestrial areas that are drained by rivers, such as the $\mathrm{Ob}$ and Yenesei, that flow to the Kara Sea. The material has been introduced into the sea in many forms, including solutions that were pumped into the sea and as solids and liquids in containers that were dumped. A large fraction of the inventory is associated with sixteen reactor pressure vessels, which will release contaminants into solution over long time periods. Six of these reactors contained spent and damaged nuclear fuel. In addition, fuel from one reactor was disposed of in a concrete and metal container. The inventory of radionuclides from these seven fuel loads (as well as the activation products contained in the vessels), as of 1993, has been estimated as 6 to $24 \mathrm{kCi}$ of actinides, $492-540 \mathrm{kCi}$ of fission products, and $125 \mathrm{kCi}$ of activation products [Mount et al, 1993]. The fission products that are present in greatest activities are ${ }^{137} \mathrm{Cs}$ and ${ }^{90} \mathrm{Sr}$, with about $120 \mathrm{kCi}$ each. Two fission products, ${ }^{99} \mathrm{Tc}$ and ${ }^{129} \mathrm{I}$, are present in relatively low quantities. However their long half-lives will make them the dominant fission products after the others have decayed away.

In order to understand and model the transport and distribution of radionuclides in the Kara Sea, resulting from dumping activities by the Former Soviet Union, two parameters are critically important:

1. Distribution Coefficients describing partitioning of radioactive contaminants between the water and the sediment (indicating relative mobility), and

2. Biological Concentration Factors for local species.

The International Arctic Seas Assessment Project of the International Atomic Energy Agency, in its progress report dated August, 1994, has identified the lack of site-specific values for these two parameters for an appropriate set of radionuclides, as a major data need. Consequently, we have investigated the sorption properties of radionuclides that are present in this waste in the greatest concentrations or those with long half-lives.

Models that describe the fate and transport of contaminants in natural systems of water and sediment require several types of data as input. For example, one data set allows calculation of fluid flow within the system while other parameters define how readily a contaminant associates with the sediment. As a result of sorption reactions on mineral grains, contaminants can concentrate on the solid phase of a water/sediment system. This will occur as contaminated water moves past the grains. As the contaminant is sorbed, with its concentration in the water consequently reduced, the rate of transport of the contaminant is retarded in proportion to how readily it is sorbed. The critical parameter, used to quantify this process is called the distribution coefficient $\left(\mathrm{K}_{\mathrm{\gamma}}\right)$. It is the concentration of the species of interest on the solid divided by its concentration in the liquid, at steady-state. The distribution coefficient is affected by factors such as grain size of the solid, its mineralogy and organic matter content, solution chemistry, and speciation of the contaminant in solution. Because of these influences, to 
determine $\mathrm{K}_{\mathrm{d}}$ values appropriate to the site under study, it is necessary to conduct experiments that come as close as reasonably possible to site specific chemical conditions and materials.

The distribution coefficient can be a non-linear function of the concentration of the contaminant in solution. Typically this becomes apparent at higher masses of sorbed contaminant; while at lower fractional uptake the relationship between the concentration of the contaminant in solution and its concentration on the solid is linear. Isotherms are used to determine if the $\mathrm{K}_{d}$ varies with solution concentration, allowing an evaluation of the relationship between sorption at differing concentrations of contaminant. An isotherm can be generated experimentally by plotting contaminant concentrations on the solid on the $\mathrm{Y}$-axis and its concentration in solution on the $\mathrm{X}$-axis. For simple linear systems the slope is $\mathrm{K}_{\mathrm{d}}$. If the relationship is linear at the relatively high tracer concentrations in the laboratory experiments, then it is appropriate to use that $K_{d}$ for the much lower concentrations typically found in the environment.

The purpose of this study is to quantify some of the parameters needed to perform nearfield modeling of sites in the Kara Sea that were impacted by the disposal of radioactive waste. The parameters of interest are: the distribution coefficients for several important radionuclides for sediment taken from the Kara Sea, the mineralogy of the sediment, and the relationship of $\mathrm{K}_{\mathrm{d}}$ to liquid to solid ratio. In addition the sediment was analyzed to determine if it contains observable quantities of anthropogenic radionuclides. Values of $K_{d}$ were determined for the radionuclides present in the waste in the greatest abundance, with the longest half-lives, and/or of particular environmental concern. These are ${ }^{90} \mathrm{Sr},{ }^{99} \mathrm{Tc},{ }^{129} \mathrm{I},{ }^{137} \mathrm{Cs},{ }^{210} \mathrm{~Pb},{ }^{232} \mathrm{U}$, and ${ }^{241} \mathrm{Am}$. The gamma-emitters ${ }^{85} \mathrm{Sr}$ and ${ }^{125} \mathrm{I}$ were substituted for ${ }^{90} \mathrm{Sr}$ and ${ }^{129} \mathrm{I}$ (both beta-emitters) respectively.

Sediment from the Kara Sea (location: $73^{\circ} 00^{\prime} \mathrm{N}, 58^{\circ} 00^{\prime} \mathrm{E}$ ) was sampled from a depth of 287 meters on August 23/24, 1992, during a joint Russian/Norwegian scientific cruise. The location is shown on Figure 1. This sediment subcore was obtained by the U. S. Environmental Protection Agency, from the Norwegian Radiation Protection Authority, and sent to Brookhaven National Laboratory for analysis. The core was split lengthwise, photographed and then sampled. Figure 2 is a photograph showing that the core liner was $39 \mathrm{~cm}$ in length, the sediment was $32.3 \mathrm{~cm}$ in length and consisted of green/black mud. There was no visible layering but there were two areas were the sediment was brownish green (at $5-7.5 \mathrm{~cm}$ and at 13 $\mathrm{cm})$. Two worm tubes were observed at $18 \mathrm{~cm}$.

The sediment from one side of the core was divided into 10 horizontal sections which were weighed, dried and reweighed. These samples were sent to the Lockheed Environmental Systems Technology Company in Las Vegas, Nevada, for radiochemical analysis. About 30 grams of the remaining sediment, from near the bottom of the core, was sent to the Army Corps of Engineers Laboratory in Marietta, Georgia, for petrographic analysis. Two samples, one from $0-6 \mathrm{~cm}$ depth in the core and the other from $26-28 \mathrm{~cm}$, were sent to the EPA's Environmental Research $\mathrm{Lab}$ at Narragansett, Rhode Island, for grain size analysis and determination of total organic carbon. The remainder was kept under an Argon atmosphere 
where it was used for analysis of its ability to sorb ${ }^{85} \mathrm{Sr},{ }^{99} \mathrm{Tc},{ }^{125} \mathrm{I},{ }^{137} \mathrm{Cs},{ }^{210} \mathrm{~Pb},{ }^{232} \mathrm{U}$, and ${ }^{241} \mathrm{Am}$. Seawater was obtained off the coast of Long Island, New York. The water was filtered $(0.45$ $\mu \mathrm{m})$ and boiled to remove air, prior to the experiments. Its salinity was about $34 \mathrm{ppt}$ which is comparable to bottom water in the Kara Sea.

\section{MINERALOGY AND OTHER SEDIMENT PARAMETERS}

The mean grain size of a surface sample was 17 microns (sand $=7.5 \%$, silt $=71.5 \%$ and clay $=21 \%$ ) the total organic carbon (TOC) was $93 \mathrm{mg} / \mathrm{g}$ in the $0-6 \mathrm{~cm}$ fraction and 80 $\mathrm{mg} / \mathrm{g}$ in the $26-28 \mathrm{~cm}$ fraction. This value is very high, even for a coastal sediment. In a recent assessment of the relationship of total organic carbon to surface area, in which TOC values were compiled for sediment from around the world, only sediment from the Peru slope had higher values [Meyer, 1994]. Mineralogy of a composite sample was dominated by quartz and feldspar in the sand and coarse silt fractions and by illite/mica, chlorite and kaolinite in the fine silt. The clay fraction was comprised primarily of mixed layer smectite $(34 \%)$, illite $(18 \%)$, chlorite $(17 \%)$ and kaolinite $(14 \%)$. The mineralogy of the sample was determined for several grain size separates and this information is shown on Table 1. Table 2 gives the mineralogy of the heavy mineral suite of this specimen.

\section{SORPTION KINETICS}

In the first set of experiments we examined the kinetics of the sorption processes. This information is necessary to define the times that are required by the different radionuclides of interest to reach steady state concentrations in the water/sediment system. Sorption kinetics experiments were conducted under argon to preserve redox conditions and any sulfide minerals. For each specimen, about $5.0 \mathrm{~g}$ of the wet sediment and the contact solution were weighed into a polyethylene centrifuge tube. The contact solution was $42.0 \mathrm{~g}$ of seawater (collected on the Atlantic coast of Long Island, New York) that had been filtered and boiled, with $1 \mathrm{~mL}$ of radioactive tracer added. Samples were taken periodically by shaking the specimen and removing about $2 \mathrm{~mL}$ of slurry with a plastic syringe. The slurry was then filtered with a 0.45 $\mu \mathrm{m}$ syringe filter and the effluent was weighed into counting vials. Analysis was performed by either liquid scintillation counting for beta emitters or by gamma spectroscopy with an intrinsic germanium gamma detecto.

The results for ${ }^{210} \mathrm{~Pb}$ are shown in Figure 3. Lead was removed extremely rapidly and completely; it was below detection limits $(0.1 \mathrm{CPM}$ or about $100 \mathrm{ng} / \mathrm{L})$ in the contact solution in about 50 hours. Figure 4 shows that uranium had much slower kinetics, requiring about 50 hours for $50 \%$ removal from solution and steady state was achieved after about 350 hours. This is probably the result of a redox reaction converting the uranium tricarbonate, which is the predominant species in seawater, to a reduced form with low solubility [Barnes and Cochran, 1993]. Figure 5 shows results for iodine. The kinetics experiment showed that iodine is not retained at all on the sediment, after what appears to be a brief period of sorption and then 
desorption. This lack of iodine uptake may be the result of high concentrations of iodine found in reducing sediments [Price and Calvert, 1973] causing a flux of iodine out of the sediment. Figure 6 shows that technetium exhibits a slow reaction kinetics that appears to become steady state after 170 hours. As with uranium this is probably a redox process with the technetium being converted from $\mathrm{TcO}_{4}{ }^{-}$to either a reduced oxide or a sulfide [Lee and Bondietti, 1983]. Cesium concentrations in the contact solution became steady state by 50 hours, as shown in Figure 7. Figure 8 illustrates that strontium became steady state after about 150 hours. Sorption kinetics data for ${ }^{241} \mathrm{Am}$ are not plotted since uptake was so rapid, with steady-state being attained within the first hour. Results are summarized in Table 3.

\section{DISTRIBUTION COEFFICIENTS}

The ratio, at steady-state, of the concentration on the sediment to the concentration in the water defines the distribution coefficient, $K_{d}$. In this case, the $K_{d}$ value is the radioactivity associated with the solid phase (as $\mathrm{cpm} / \mathrm{g}$ ) divided by the activity in the liquid (as $\mathrm{cpm} / \mathrm{mL}$ ). It is a critical parameter that describes the degree to which a sediment will retain or immobilize a contaminant. In this study $\mathrm{K}_{\mathrm{d}}$ values were determined experimentally for ${ }^{137} \mathrm{Cs},{ }^{85} \mathrm{Sr},{ }^{99} \mathrm{Tc},{ }^{125} \mathrm{I}$, ${ }^{232} \mathrm{U}$ and ${ }^{241} \mathrm{Am}$ using batch type tests. Measurements for ${ }^{210} \mathrm{~Pb}$ were not made since the kinetics experiment showed complete removal of lead. These measurements were made under an Ar atmosphere to eliminate artifacts caused by oxidation of reduced minerals. Seawater that had been filtered and boiled (to remove oxygen) was used as the contact solution. The radionuclides were prepared by dilution with distilled water and, for the final dilution, with filtered and boiled seawater. In these tests about 1.0 gram of wet sediment was weighed into pre-weighed plastic centrifuge tubes. Twenty five grams of seawater and $0.5 \mathrm{~mL}$ of radioactive tracer solution were added. After several days the liquid was sampled with plastic disposable syringes and filtered through $0.45 \mu \mathrm{m}$ syringe filters. The kinetics data obtained earlier was used to determine the minimum time required for the batch tests.

Average $K_{d}$ values determined in this study and the time required for the kinetics experiments to reach steady-state are given in Table 3. Detailed results of the triplicate batch sorption experiments are given in Table 4. The samples noted as "ref" on these tables are the reference solutions of seawater and tracer that were handled in the same manner as the samples, including filtration. These values were then used to determine the activity in the beginning solution from which the activity sorbed was calculated by subtracting the activity in the sample liquid from the reference activity. Determination of the distribution coefficient is influenced by uncertainties in the analysis, particularly if the count rate in the liquid phase is very low compared to the solid phase. Ideally the activity on the solid should be similar to that in the liquid. In most cases, in this set of experiments, activities in both phases were acceptable (compare the reference activities in Table 4 to those of the samples). However, in the case of americium, the $\mathrm{K}_{\mathrm{d}}$ is sufficiently high that very little 


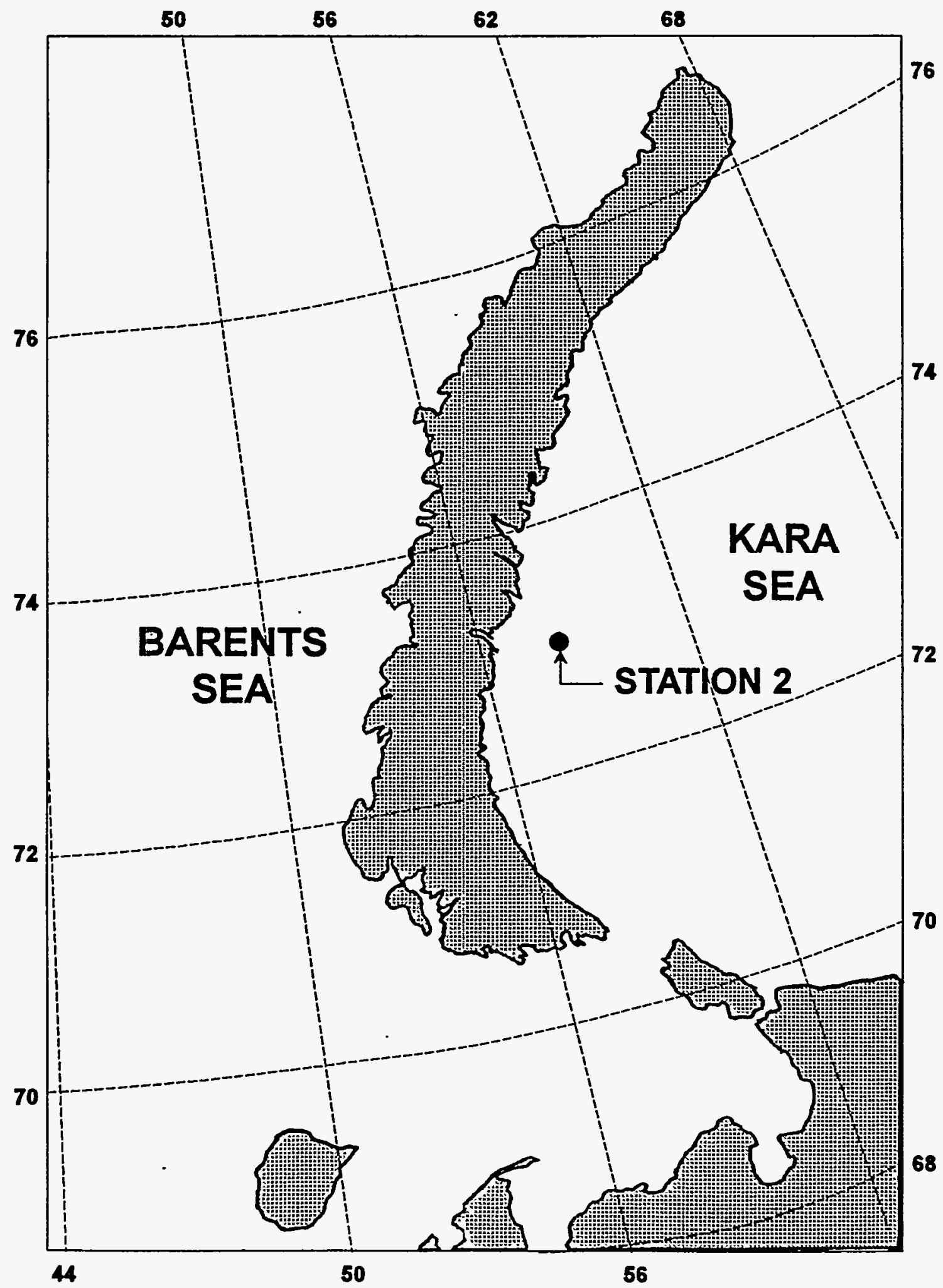

Figure 1 The Kara Sea near Novaya Zemlya, showing the location from which the sediment sample was taken. 


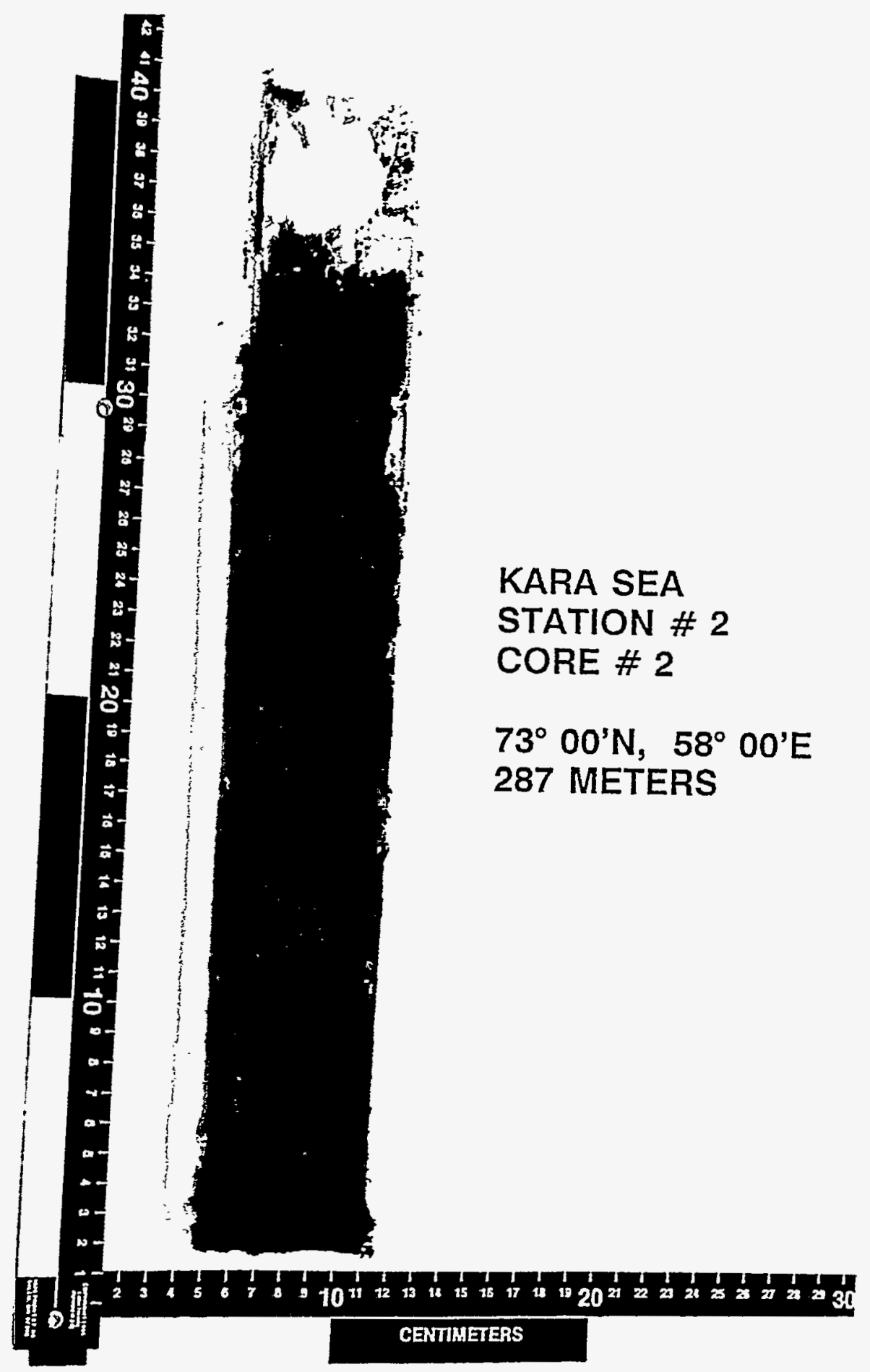

Figure 2 The sediment core after sectioning. It had thawed and settled before receipt at BNL, but was still suboxic throughout. 
Table 1 Mineral Composition of Sediment Sample, Kara Sea, Station 2

\begin{tabular}{|c|c|c|c|c|c|c|c|c|c|}
\hline & \multicolumn{4}{|c|}{ SAND } & \multicolumn{3}{|c|}{ SILT } & \multirow{2}{*}{$\frac{\text { CLAY }}{<.002}$} & \multirow[t]{2}{*}{ AVG. } \\
\hline Size $(\mathrm{mm})$ & +2.0 & $\begin{array}{c}2.00 \text { to } \\
0.42\end{array}$ & $\begin{array}{c}0.42 \text { to } \\
0.18\end{array}$ & $\begin{array}{c}0.18 \text { to } \\
.074\end{array}$ & $\begin{array}{c}.074 \text { to } \\
.044\end{array}$ & $\begin{array}{c}.044 \text { to } \\
.010\end{array}$ & $\begin{array}{c}.010 \text { to } \\
.002\end{array}$ & & \\
\hline Weight \% & 0.0 & 0.6 & 3.2 & 11.7 & 6.4 & 19.4 & 35.1 & 23.6 & \\
\hline \multicolumn{10}{|c|}{ Percent Composition } \\
\hline Rock (1) Particles & - & 40 & 8 & $\mathrm{~T}$ & - & - & - & - & 1 \\
\hline Quartz & - & 53 & 68 & 64 & 76 & 35 & 17 & 8 & 30 \\
\hline Feldspar & - & 5 & 20 & 30 & 20 & 13 & 5 & 4 & 11 \\
\hline H. Min. (2) & - & $\mathrm{T}$ & 1 & 3 & 1 & 1 & 1 & - & 1 \\
\hline Smectite M/L & - & - & - & - & - & $T$ & 2 & 34 & 9 \\
\hline Illite/mica & - & $\mathrm{T}$ & 1 & 1 & 1 & 28 & 33 & 18 & 21 \\
\hline Chlorite & - & - & - & - & - & 12 & 18 & 17 & 13 \\
\hline Kaolinite & - & - & - & - & - & 6 & 18 & 14 & 10 \\
\hline Zeolite & - & - & - & - & - & - & 1 & - & $T$ \\
\hline Other & - & 2 & 2 & 2 & 2 & 5 & 5 & 5 & 4 \\
\hline
\end{tabular}

1. Rock Particles, in order of abundance, includes dark gray to black metasediment, tan quartzite, gray gneiss, tan to gray dolomite, and gray mica schist.

2. Heavy Minerals (S.G. greater than 3.0) include, in order of abundance, garnet, amphiboles, epidote, staurolite, opaques, orthopyroxene, zircon, rutile, and minor other.

3. Other, in order of abundance, includes chert, glauconite, calcite, and metal shavings. The metal shavings occur in trace amounts in the coarse fraction. The particles have a silver color, metallic luster, curved shape, and react with dilute hydrochloric acid.

4. $\mathrm{T}=$ trace amounts (less than $0.5 \%$ ) 
Table 2 Average Composition of Heavy Mineral Suite Kara Sea Sediment Sample, Station 2

\begin{tabular}{||l|c|}
\hline \multicolumn{1}{|c|}{ Mineral Species } & Percent Composition \\
\hline Opaque Minerals (1) & 8 \\
\hline Garnet Group & 32 \\
\hline Amphibole Group (2) & 26 \\
\hline Epidote Group & 18 \\
\hline Staurolite & 9 \\
\hline Orthopyroxene & 2 \\
\hline Rutile & 1 \\
\hline Zircon & 1 \\
\hline Other & 3 \\
\hline
\end{tabular}

1. Opaque minerals, in order of abundance: ilmenite, leucoxene, magnetite, minor other constituents.

2. Amphibole group, in order of abundance: dark green hornblende, brown hornblende, white tremolite, minor other constituents.

3. Other miscellaneous minerals, in order of abundance: sillimanite, chlorite, apatite, monazite. 
Table 3

Kinetics and Average $K_{d}$ Values

\begin{tabular}{|c|c|c||}
\hline RADIONUCLIDE & $\begin{array}{c}\text { SORPTION KINETICS } \\
\text { Hours to Steady- State }\end{array}$ & $\begin{array}{c}\text { AVERAGE } \\
\mathbf{K}_{\mathbf{d}}(\mathrm{mL} / \mathrm{g})\end{array}$ \\
\hline $\mathrm{Sr}-85$ & 150 & 5 \\
\hline $\mathrm{Tc}-99$ & 200 & 43 \\
\hline $\mathrm{I}-125$ & 50 & 56 \\
\hline $\mathrm{Cs}-137$ & 50 & 280 \\
\hline $\mathrm{Pb}-210$ & 50 & $>20,000 *$ \\
\hline $\mathrm{U}-232$ & $>350$ & 23 \\
\hline $\mathrm{Am}-241$ & $<1$ & $>5800$ \\
\hline
\end{tabular}

* Based on the detection limits for ${ }^{210} \mathrm{~Pb}$ at the geometry used, the mass of sediment and the quantity of liquid in the kinetics experiment. 


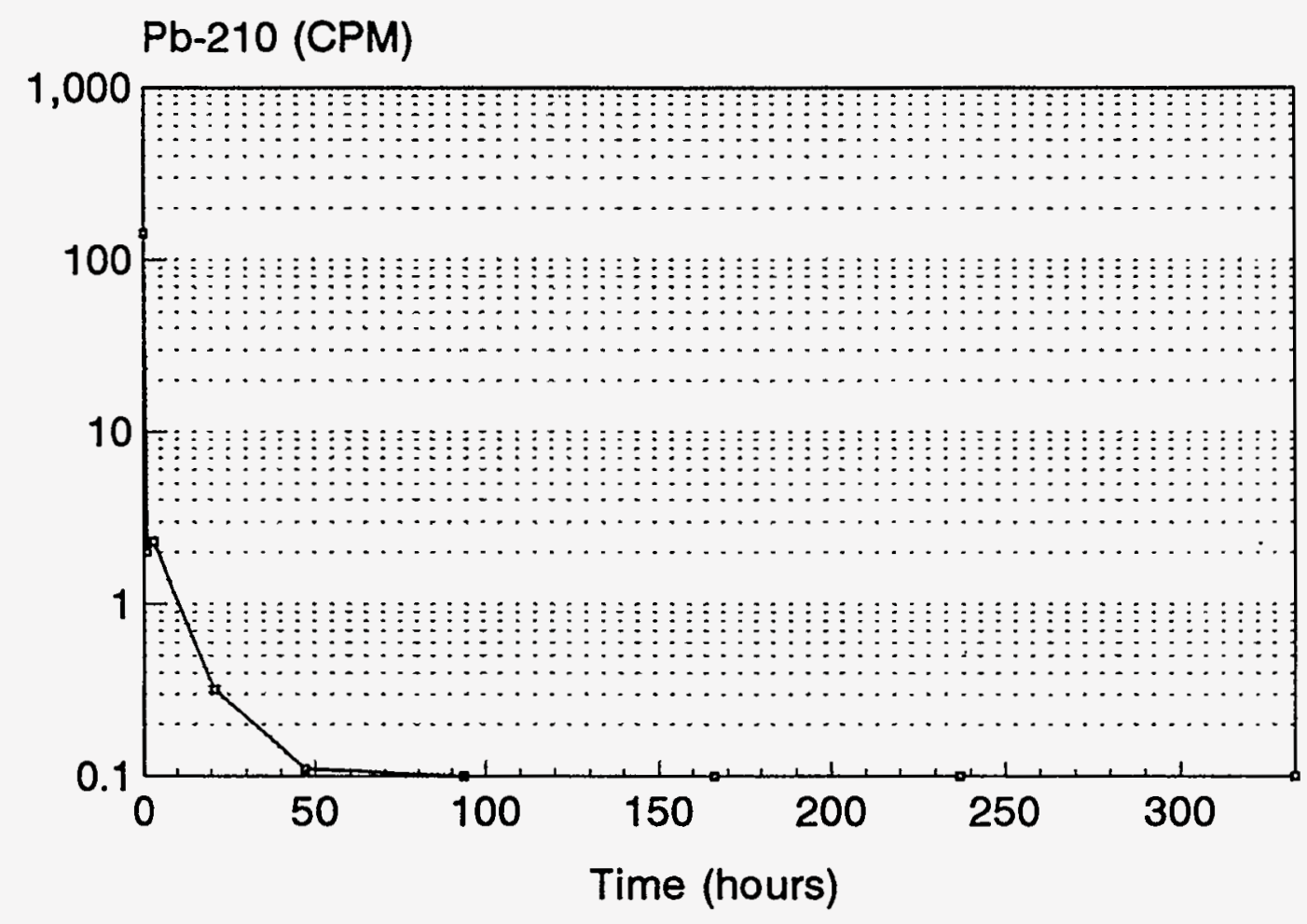

Figure 3 Sorption kinetics of lead on Kara Sea sediment, steady state uptake took about 50 hours. 


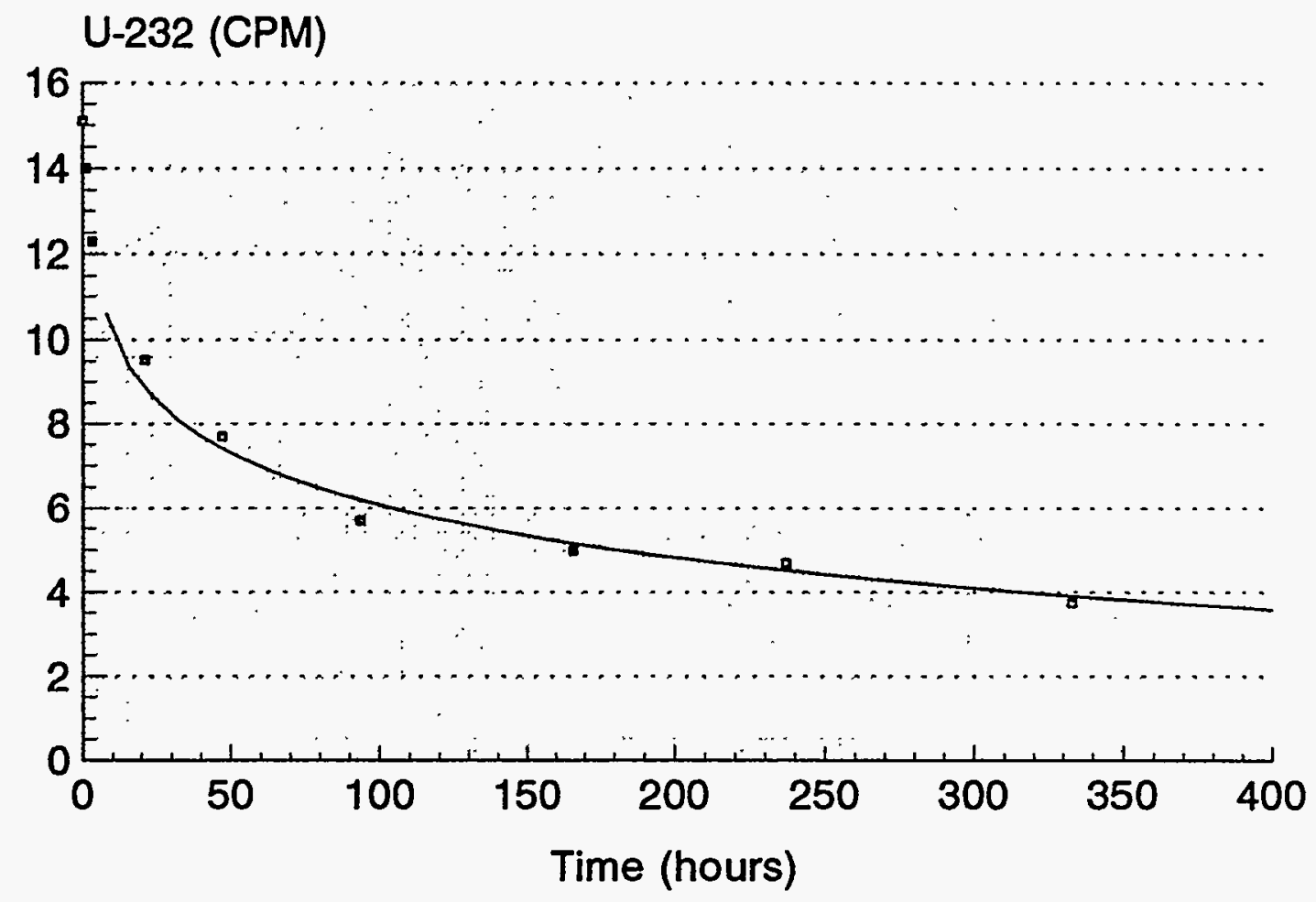

Figure 4 Sorption kinetics of uranium on Kara Sea sediment, the time to steady state was more than 350 hours. 


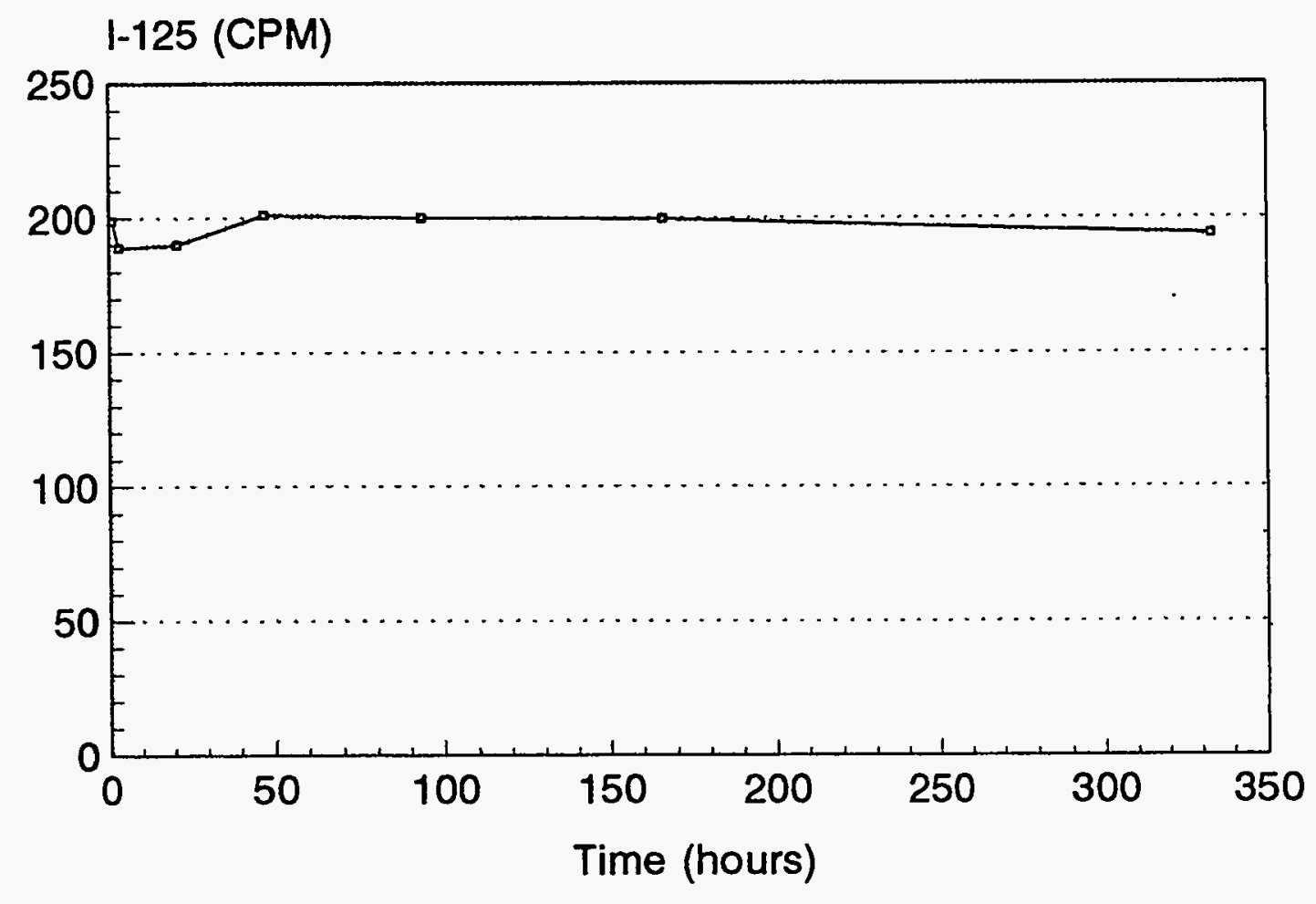

Figure 5 Sorption kinetics of iodine on Kara Sea sediment. Iodine was initially sorbed and then desorbed, with no total uptake observed after 50 hours. 


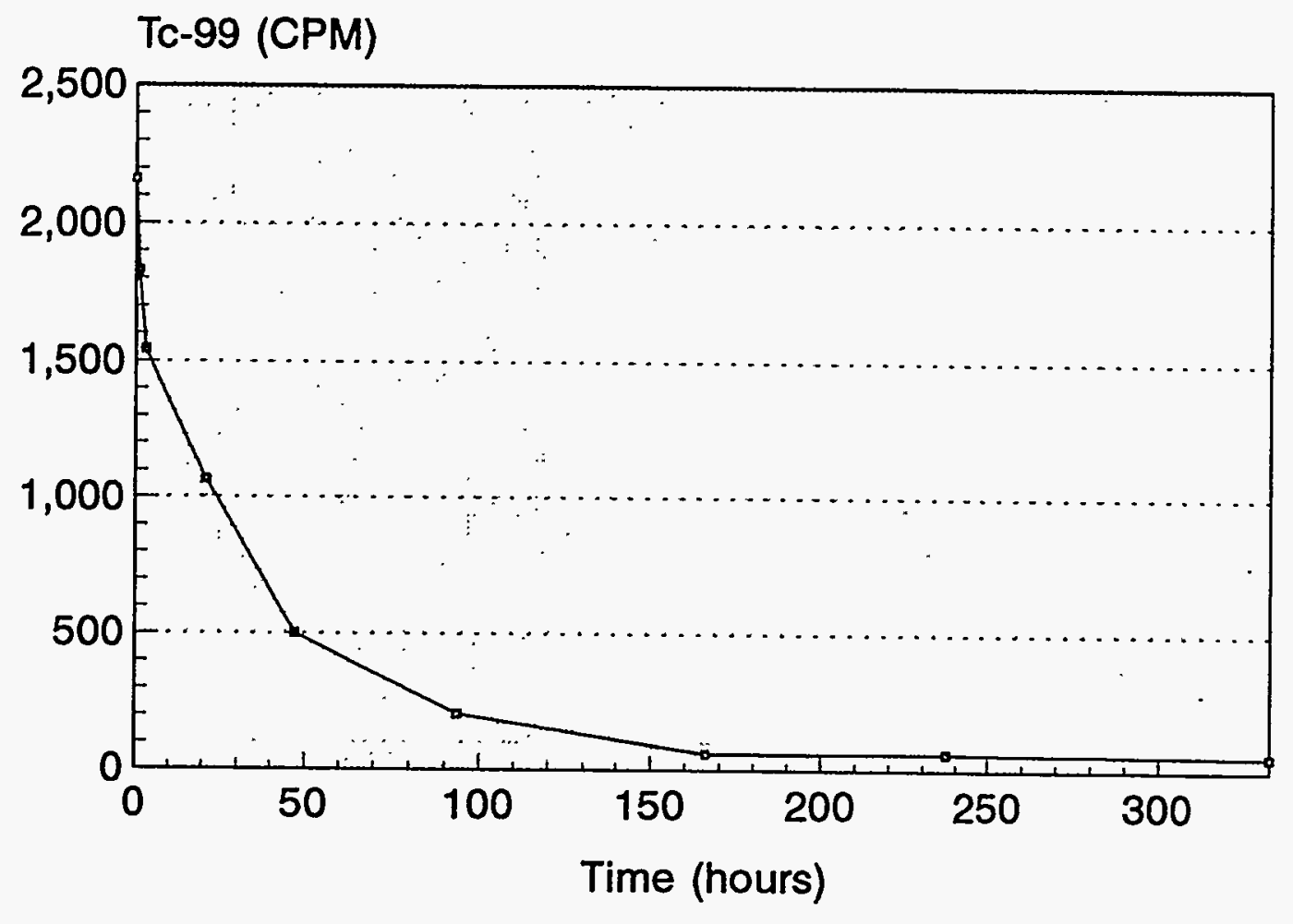

Figure 6 Sorption kinetics of technetium on sediment from the Kara Sea. Uptake was steady state after about 170 hours. 


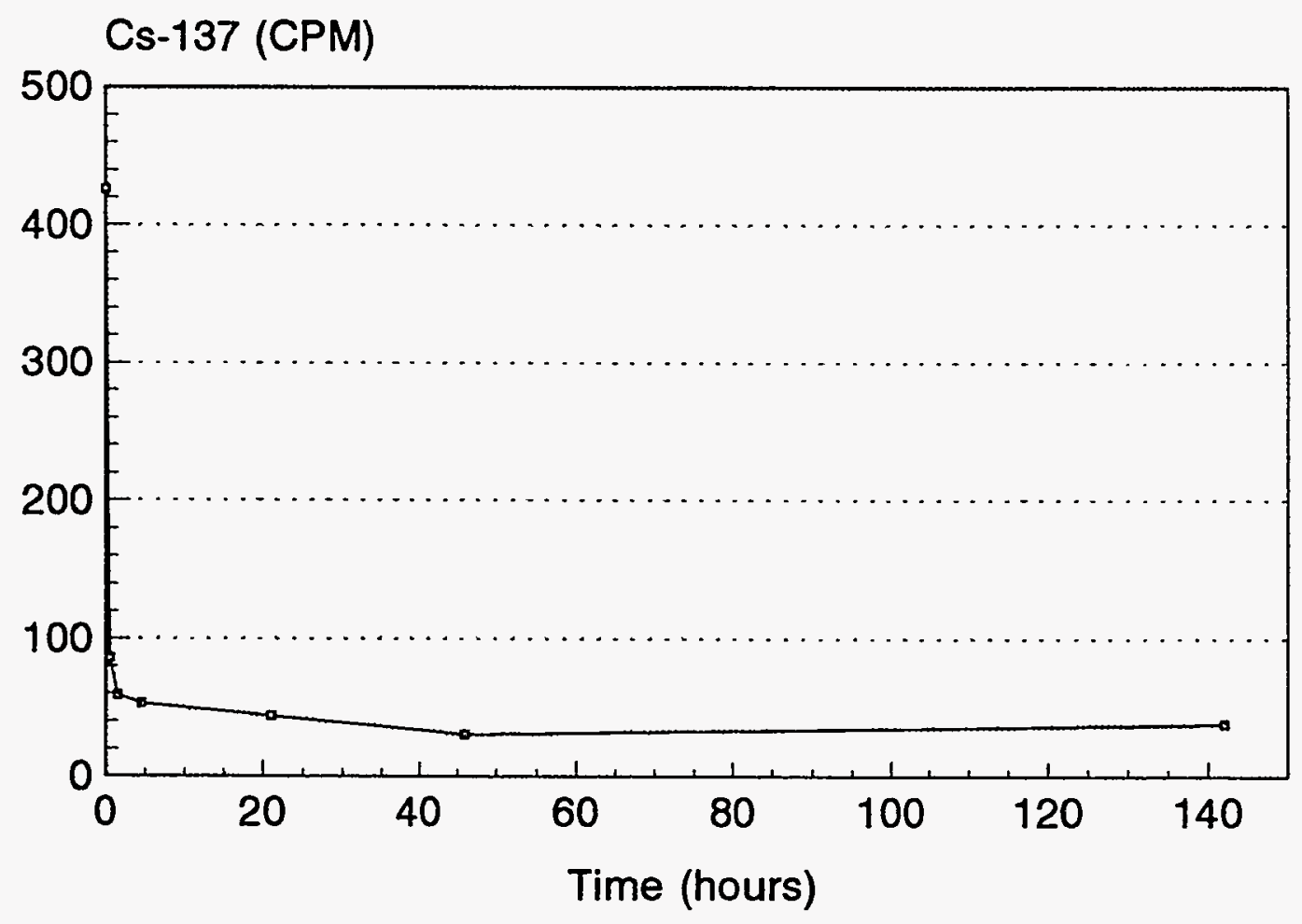

Figure 7 Sorption kinetics of cesium on sediment from the Kara Sea. Uptake was steady state after about 50 hours. 


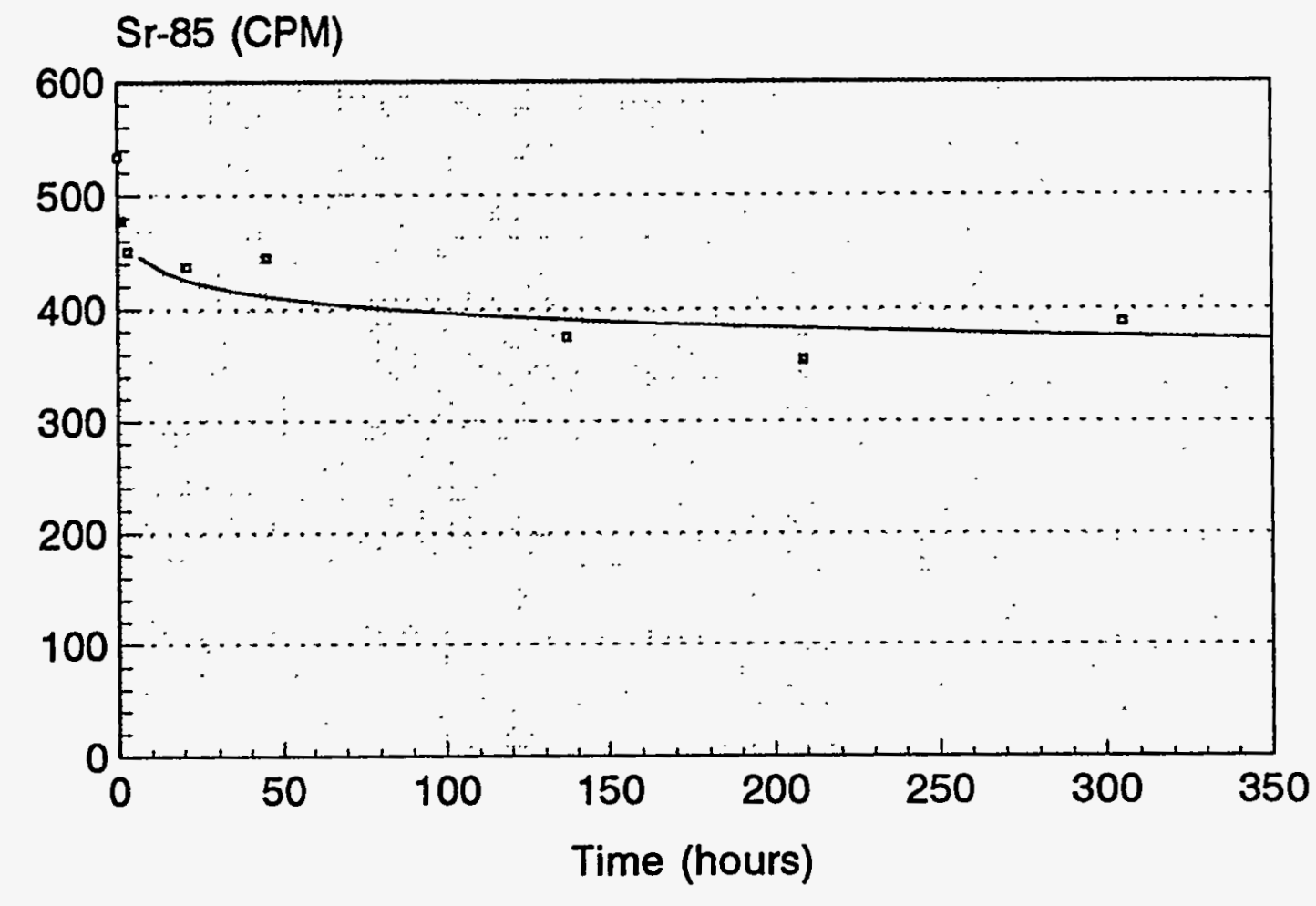

Figure 8 Sorption kinetics of strontium on Kara Sea sediment. Uptake was steady state after 150 hours. 
Table 4

$K_{D}$ Values for Radionuclides on Kara Sea Sediment

\begin{tabular}{|c|c|c|c|c|c|c|}
\hline Sample & $\begin{array}{c}\text { Sediment } \\
\text { Dry Wt }\end{array}$ & $\begin{array}{l}\text { Total } \\
\text { Liquid }\end{array}$ & $\begin{array}{l}\text { Activity in } \\
\text { Liquid, } \\
\text { cpm/mL }\end{array}$ & $\begin{array}{l}\text { Delta } \\
\text { cpm/ml }\end{array}$ & $\begin{array}{c}\begin{array}{c}\text { Activity on } \\
\text { Solid } \\
\text { cpm/g }\end{array} \\
\end{array}$ & $\begin{array}{c}\mathrm{Kd} \\
\mathrm{mL} / \mathrm{g}\end{array}$ \\
\hline Cs $A$ & 0.575 & 25.76 & 3.40 & 18.86 & 844.5 & 249 \\
\hline Cs B & 0.651 & 26.10 & 3.44 & 18.82 & 754.8 & 219 \\
\hline Cs C & 0.582 & 26.22 & 3.66 & 18.60 & 837.5 & 229 \\
\hline Cs Ref & 0.000 & 25.64 & 22.3 & -- & -- & --. \\
\hline Tc $A$ & 0.637 & 25.61 & 58.3 & 62.9 & 2530 & 43.4 \\
\hline Tc B & 0.514 & 25.57 & 52.0 & 69.2 & 3440 & 66.2 \\
\hline Tc C & 0.623 & 25.65 & 81.7 & 39.5 & 1630 & 19.9 \\
\hline Tc Ref & 0.000 & 25.47 & 121 & --- & --- & --- \\
\hline Sr A & $\cdot 0.548$ & 25.55 & 3.56 & 0.7 & 32.6 & 9.2 \\
\hline Sr B & 0.596 & 25.71 & 3.97 & 0.29 & 12.5 & 3.2 \\
\hline $\mathrm{SrC}$ & 0.637 & 25.70 & 3.91 & 0.35 & 14.1 & 3.6 \\
\hline Sr Ref & 0.000 & 25.46 & 4.26 & -- & -- & -- \\
\hline I A & 0.541 & 25.62 & 12.60 & 6.8 & 321.9 & 25.5 \\
\hline I B & 0.493 & 25.59 & 9.50 & 9.9 & 513.6 & 54.1 \\
\hline I C & 0.486 & 25.52 & 7.30 & 12.1 & 635.0 & 87.0 \\
\hline I Ref & 0.000 & 25.55 & 19.40 & -- & --- & $\cdots$ \\
\hline Am $\mathrm{A}$ & 0.452 & 25.51 & 0.09 & 11.6 & 654.5 & 7420 \\
\hline Am B & 0.500 & 25.53 & 0.12 & 11.57 & 590.7 & 4880 \\
\hline $\mathrm{Am} \mathrm{C}$ & 0.507 & 25.58 & 0.11 & 11.58 & 584.4 & 5250 \\
\hline Am Ref & 0.000 & 25.38 & 11.69 & --- & --- & --- \\
\hline $\mathrm{UA}$ & 0.404 & 25.83 & 3.53 & 1.56 & 99.7 & 28.3 \\
\hline U B & 0.596 & 26.02 & 3.76 & 1.33 & 58.1 & 15.4 \\
\hline $\mathrm{U} \mathrm{C}$ & 0.507 & 26.43 & 3.46 & 1.63 & 85.0 & 24.5 \\
\hline U Ref & 0.000 & 25.50 & 5.09 & --- & --- & --- \\
\hline
\end{tabular}


americium remains in solution. Due to the way in which $\mathrm{K}_{\mathrm{d}}$ is calculated, when the count rate in the liquid is low compared to the rate on the solid, very small changes of activity in the liquid can result in large changes in $\mathrm{K}_{\mathrm{d}}$. Consequently the results reported for Am are minimum values of $K_{d}$, because the activities of americium in the liquid phase are below the minimum activity that is detectable.

To examine the effect that changing concentrations of tracers have on the quantity sorbed, isotherms were developed for ${ }^{137} \mathrm{Cs},{ }^{85} \mathrm{Sr}$ and ${ }^{99} \mathrm{Tc}$. Isotherms are plots of the concentration of a species of interest in the liquid (on the $\mathrm{x}$-axis) versus the concentration of that species on the solid, at steady-state. Several concentrations are used to define a line on the plot which can be used to make inferences about the processes controlling sorption. Experiments, comprised of 5 concentrations, were run for each of the three radionuclides. For each sample, 1 gram of dry sediment was weighed into a polyethylene centrifuge tube and 22.0 to $24.5 \mathrm{~g}$ of seawater were then weighed in. The quantity of seawater varied depending on how much tracer was added, the sum of the two being about $25.0 \mathrm{~g}$. In each case the final dilution of the tracer was made with seawater and was close to neutral $\mathrm{pH}$. Times to sampling were determined by the kinetics experiments performed earlier. Results of these experiments are summarized on Table 5.

The isotherm for ${ }^{137} \mathrm{Cs}$ is shown in Figure 9. A typical isotherm is expected to have a positive slope (the slope being the value of $\mathrm{K}_{\mathrm{d}}$ ). The activity of the starting concentrations of tracer used in this series of experiments ranged from about 18 to $100 \mathrm{~Bq} / \mathrm{mL}$; activities that are in a range that could be expected in leachate from waste disposed of in the ocean. At these activities the mass of cesium in the tracer is extremely low (the specific activity of the carrierfree ${ }^{137} \mathrm{Cs}$ is calculated to be $2.8 \times 10^{-17}$ Moles/ $\mathrm{Bq}$, adding to the samples from $5 \times 10^{-13}$ to 3 $\times 10^{-12} \mathrm{Moles} / \mathrm{L}$ ). This concentration is trivial compared to the concentration of $\mathrm{Cs}$ in seawater $\left(1.5 \times 10^{-8} \mathrm{Moles} / \mathrm{kg}\right)$. Results of the isotherm experiment indicate that uptake of ${ }^{137} \mathrm{Cs}$ is proportional to its concentration in solution; consequently the isotherm is linear with a positive slope. Its slope, corresponding to the overall $\mathrm{K}_{d}$ of the sample set of five concentrations, is 360 $\mathrm{mL} / \mathrm{g}$ and the correlation coefficient $\left(\mathrm{R}^{2}\right)$ is 0.90 , indicating a good fit of the data to a linear regression. To compare results from the triplicate set of batch tests (results on Table 4) these points have been plotted on the isotherm. Noting that the liquid to sediment (solid) ratio is somewhat different (50:1 vs $25: 1$ ) the values are comparable (effects of liquid to sediment ratio are discussed below). Another plot, Figure 10, illustrates that the quantity of ${ }^{137} \mathrm{Cs}$ sorbed per gram of sediment as a function of the starting concentration in the contact solution, is also proportional. In this plot the batch test results fall right on the regression line which has an $\mathrm{R}^{2}$ value of 0.97 , indicating a very good fit.

The isotherm for ${ }^{85} \mathrm{Sr}$ is shown in Figure 11 and it too is linear over its range. The batch test triplicate points from Table 4 have also been plotted and they fall on the trend. Including these points, the slope $\left(\mathrm{K}_{f}\right)$ is $3.2 \mathrm{~mL} / \mathrm{g}$ and $\mathrm{R}^{2}$ is 0.91 . Figure 12 illustrates the relationship between the quantity of ${ }^{85} \mathrm{Sr}$ sorbed and the starting concentration of the contact solution.

The isotherm for ${ }^{99} \mathrm{Tc}$ is shown in Figure 13. The five points for the isotherm and the three replicates of the batch test for ${ }^{99} \mathrm{Tc}$ are shown. The isotherm points are fit by a linear 
regression with a slope of 3.9 and an $R^{2}$ value of 0.74 . The three points from the batch test indicate significantly more uptake onto the sediment than from the isotherm test. The scatter in the batch data is also greater than usual. The reason for the differences in the two sets of data is unclear, but it may represent chemical changes in the sediment. The effect of the starting activity of ${ }^{99} \mathrm{Tc}$ in the contact solution on the $\mathrm{K}_{\mathrm{d}}$ value is shown in Figure 14.

Redox chemistry is an important factor in the uptake/immobilization of Tc. Technetium is known to exist in valence states from -1 to +7 (with $0,+7$ and +4 being the most stable). Under most natural conditions it is generally found as $\mathrm{TcO}_{4}^{-}$which forms highly soluble compounds. Technetium in the +4 state may be found in compounds such as $\mathrm{Tc}_{2} \mathrm{O}_{4}, \mathrm{Tc}(\mathrm{OH})_{4}$ and $\mathrm{TcO}_{2} \cdot \mathrm{H}_{2} \mathrm{O}$. This compound is apparently unstable and slowly looses water to become $\mathrm{TcO}_{2}$. Solubility of $\mathrm{TcO}_{2}$ is between $10^{-12}$ and $10^{-14}$ moles/L [Salter,1984]. Myers et al [1986] observed the presence of a consistent quantity of $\mathrm{TcO}_{4}^{-}$in association with oxides of $\mathrm{Tc}^{+4}$. This may have been due to small amounts $\left(6 \times 10^{-10}\right.$ moles/L) of oxygen in their experimental system or due to oxygen evolved during radiolysis of water near the $\mathrm{TcO}_{2}$ solid. Solubility of $\mathrm{Tc}^{+4}$ in contact with the solid oxide was $10^{-8}$ moles/ $\mathrm{L}$ at $\mathrm{pH}$ values between 4 and 10 [Meyer et al, 1986]. The ionic radius of $\mathrm{Tc}^{+4}$ is similar to that of $\mathrm{Fe}^{+3}$ which may allow substitution into iron compounds. Technetium sulfides with low solubilities, such as $\mathrm{Tc}_{2} \mathrm{~S}_{7}$ and $\mathrm{TcS}_{2}$ [Kotegov et al, 1979] can form, but apparently only in strong acid solutions. $\mathrm{Tc}_{2} \mathrm{O}_{7}$ is a volatile compound (Perrier and Segre, 1939). There is some evidence that $\mathrm{Tc}^{+4}$ species can exist as colloidal sized particles [Noll, 1975].

Processes involving soil microbiota and organic matter appear to influence the behavior of Tc [Wildung et al, 1979]. There are several lines of evidence from short-term experiments (24 hours) that indicate reactions of Tc with organic matter: 1) soils with low carbon content tend to have low sorption capacities for Tc, 2) sorption is reduced following digestion of soil in peroxide and 3) some Tc can be recovered from sorption on soils by extraction with $\mathrm{NaOH}$. Longer duration experiments implicate microbiological processes in the uptake of Tc [Landa et al, 1977].

Based on the small amount of previous work done with Tc sorption mechanisms, none of which was done with marine sediment, it is reasonable to believe that some minor alteration of the sediment has taken place over time which has effected the Tc uptake. The high values for Total Organic Carbon contained in this sediment make this a reasonable possibility since the material was stored at room temperature in the glovebox.

An observation, one that needs to be examined in more detail, is related to the background counts observed in the liquid scintillation analysis for the isotherm data. When the five points are plotted as the activity of ${ }^{99} \mathrm{Tc}$ in solution versus the quantity of tracer added, the effect is essentially the same as the method of standard additions. Consequently when the regression line is extended to zero $\mathrm{mL}$ of tracer added, the intercept indicates the counts obtained as background. This is shown in Figure 15. This background value is 87.9 counts per minute (cpm) for a $2 \mathrm{~mL}$ sample, in contrast to about $33 \mathrm{cpm}$ for a $2 \mathrm{~mL}$ sample of seawater. There was very little difference in the quenching of the samples. The most apparent explanation is release of a radioactive species from the sediment. 
Table 5

Isotherm Data for $\mathrm{Cs}, \mathrm{Sr}$ and $\mathrm{Tc}$

\begin{tabular}{||c|c|c|c|c|c|c||}
\hline Sample & $\begin{array}{c}\text { Sediment } \\
\text { Dry Wt (g) }\end{array}$ & $\begin{array}{c}\text { Total } \\
\text { Liquid } \\
\text { (g) }\end{array}$ & $\begin{array}{c}\text { Tracer } \\
\text { Added } \\
\text { (g) }\end{array}$ & $\begin{array}{c}\text { Activity in } \\
\text { Liquid } \\
\text { (cpm/mL) }\end{array}$ & $\begin{array}{c}\text { Activity on } \\
\text { Solid } \\
\text { (cpm/g) }\end{array}$ & $\begin{array}{c}\text { Kd } \\
\text { (mL/g) }\end{array}$ \\
\hline Cs 1 & 0.85 & 25.26 & 0.50 & 1.87 & 790 & 420 \\
\hline Cs 2 & 1.02 & 25.00 & 1.00 & 3.60 & 1320 & 370 \\
\hline Cs 3 & 1.03 & 25.01 & 1.50 & 5.74 & 1950 & 340 \\
\hline Cs 4 & 1.04 & 25.09 & 2.00 & 5.85 & 2620 & 450 \\
\hline Cs 5 & 1.1 & 25.04 & 0.75 & 1.76 & 940 & 540 \\
\hline Cs ref & 0 & 11.54 & 0.50 & 62.3 & - & -- \\
\hline \hline Sr 1 & 0.96 & 25.22 & 0.50 & 22.9 & 42.2 & 1.8 \\
\hline Sr 2 & 1.21 & 25.05 & 1.00 & 44.4 & 103 & 2.3 \\
\hline Sr 3 & 1.02 & 25.12 & 1.53 & 68.8 & 161 & 2.3 \\
\hline Sr 4 & 1.07 & 25.06 & 2.06 & 85.9 & 369 & 4.3 \\
\hline Sr 5 & 1.07 & 25.13 & 3.04 & 132 & 403 & 3.0 \\
\hline Sr ref & 0 & 11.52 & 0.50 & 53.7 & $-\cdots$ & $-\cdots$ \\
\hline \hline Tc 1 & 0.90 & 25.13 & 0.50 & 33.7 & 23.3 & 0.7 \\
\hline Tc 2 & 0.99 & 25.00 & 1.00 & 54.4 & 378 & 7.0 \\
\hline Tc 3 & 0.89 & 24.95 & 1.48 & 85.9 & 476 & 5.5 \\
\hline Tc 4 & 1.00 & 25.01 & 2.00 & 124 & 378 & 3.1 \\
\hline Tc 5 & 0.84 & 25.14 & 2.92 & 177 & 741 & 4.2 \\
\hline Tc ref & 0 & 13.00 & 2.00 & 267 & - & $-\ldots$ \\
\hline
\end{tabular}




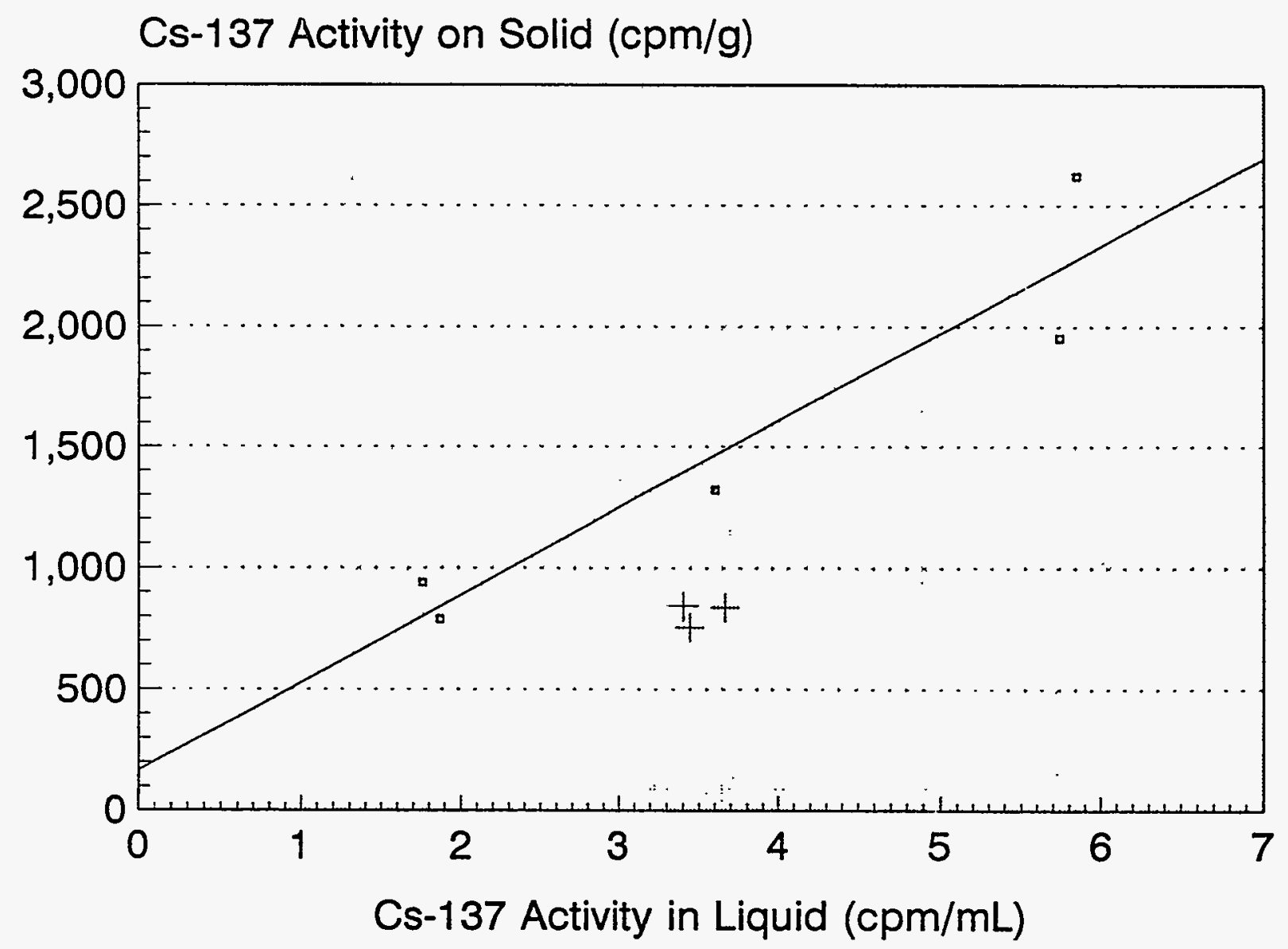

Figure 9 The isotherm for Cs-137. Also shown are the points for the triplicate $\mathrm{K}_{d}$ experiments. The slope of the regression line is $360 \mathrm{~mL} / \mathrm{g}$ and $\mathrm{R}^{2}=0.90$. 


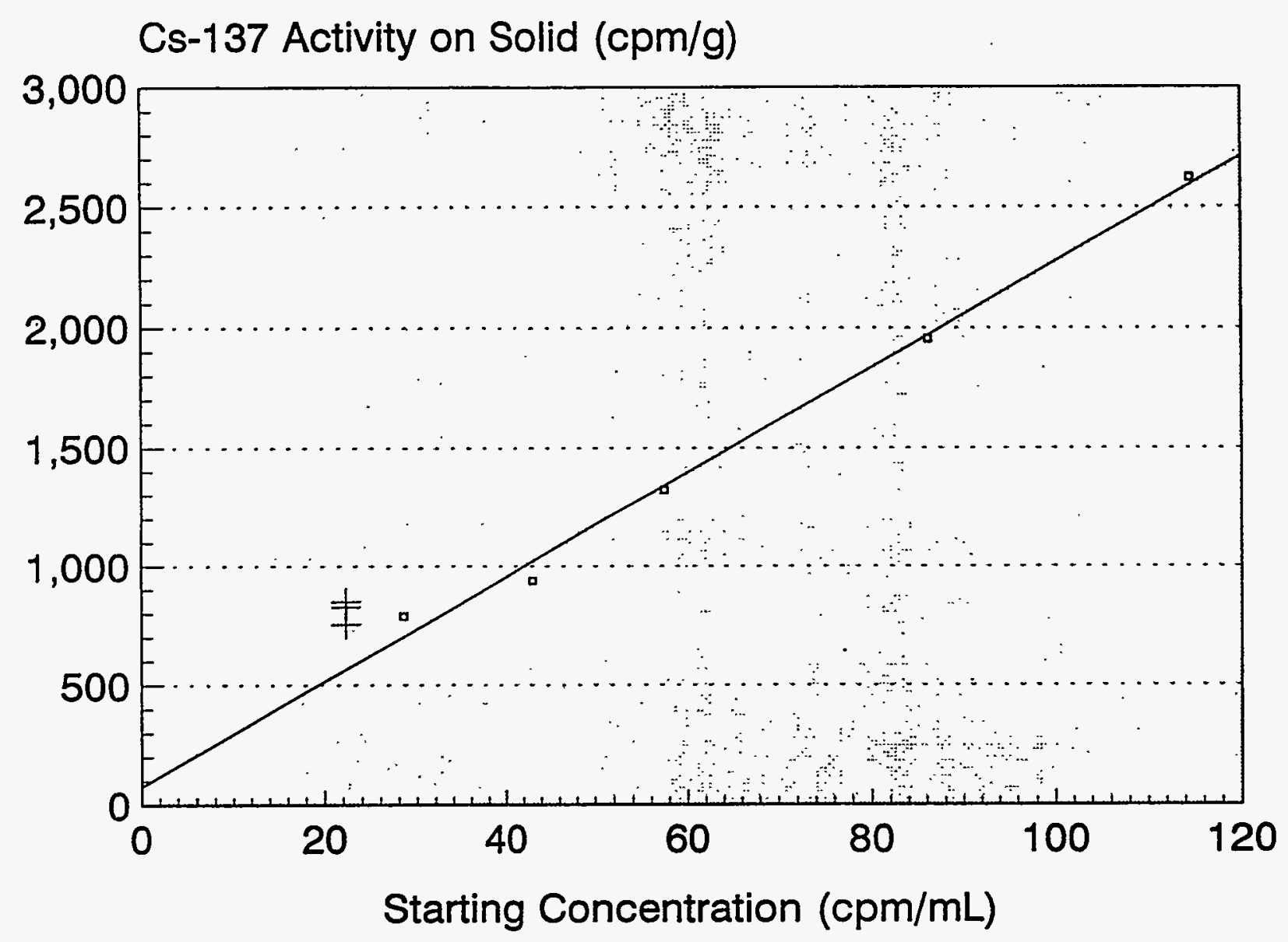

Figure 10 The quantity of ${ }^{137} \mathrm{Cs}$ sorbed per gram of sediment as a function of the starting activity of ${ }^{137} \mathrm{Cs}$ in the contact solution. Points from the triplicate batch experiment are included in the regression. 


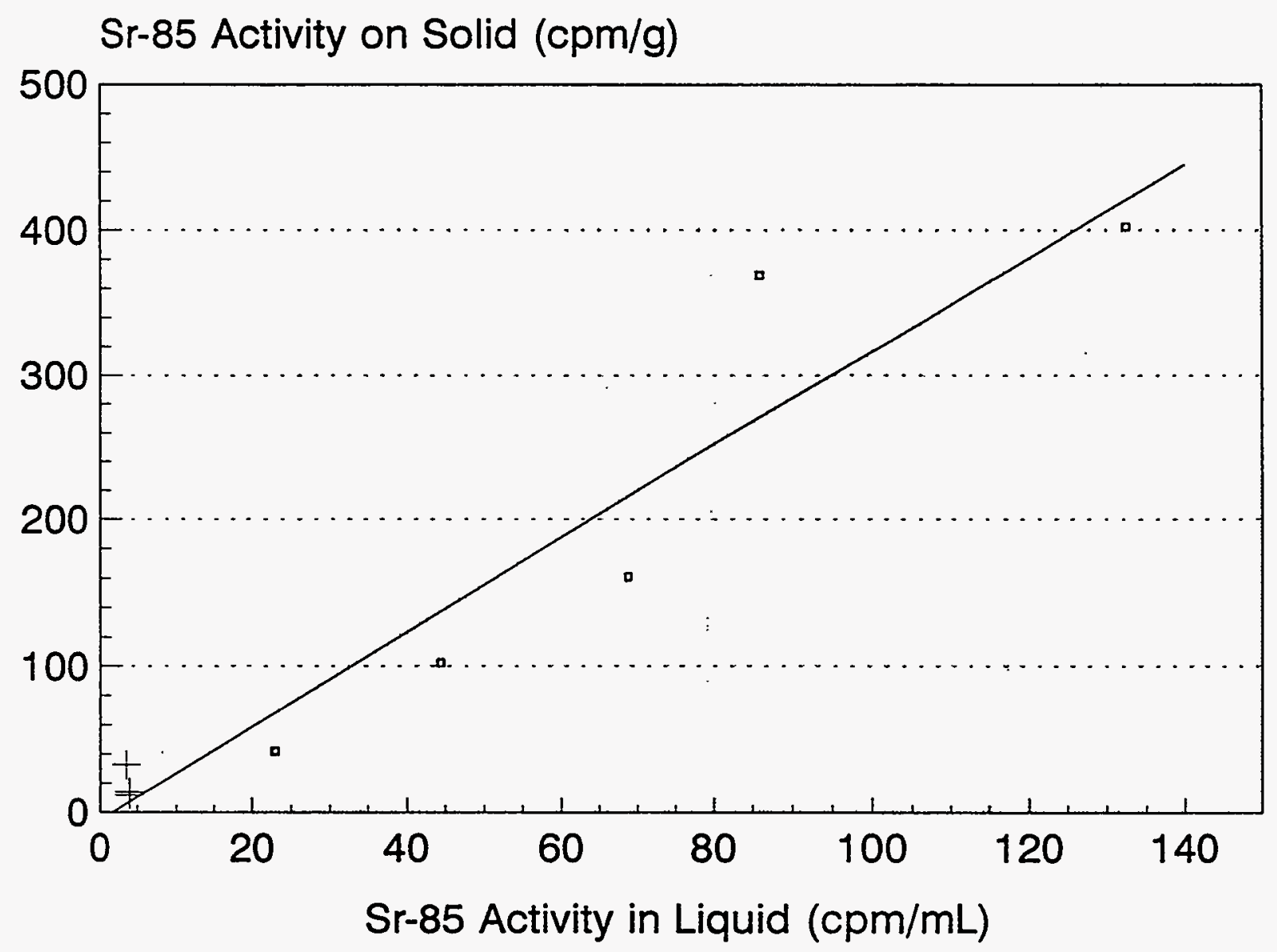

Figure 11 The isotherm for ${ }^{85} \mathrm{Sr}$, showing that with the exception of one point all data, including that from the triplicate batch experiments, fall on the regression. The slope is $3.2 \mathrm{~mL} / \mathrm{g}$ and $\mathrm{R}^{2}$ is 0.91 . 


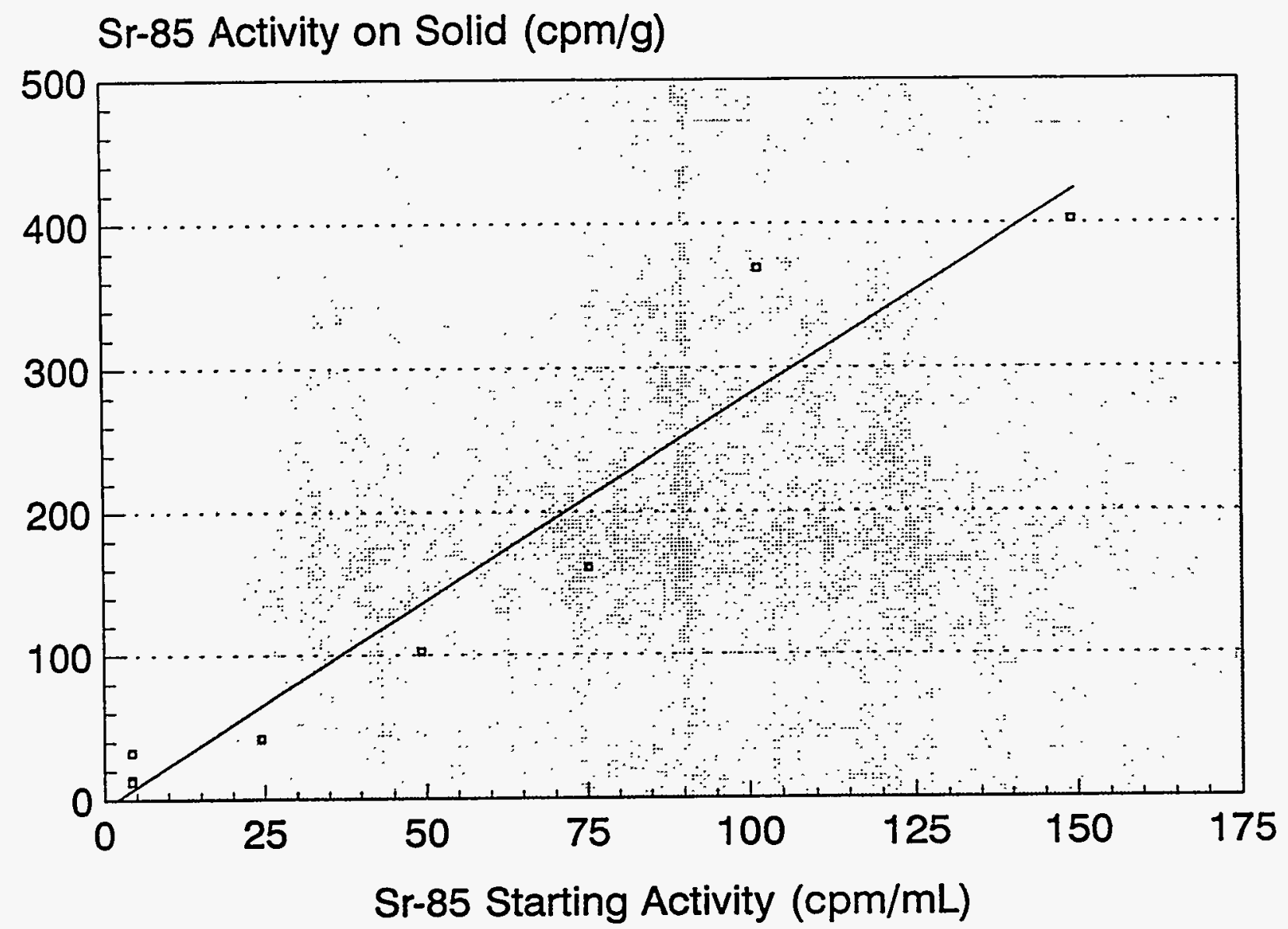

Figure 12 The quantity of ${ }^{85} \mathrm{Sr}$ sorbed per gram of sediment as a function of the starting activity of ${ }^{85} \mathrm{Sr}$ in the contact solution. 


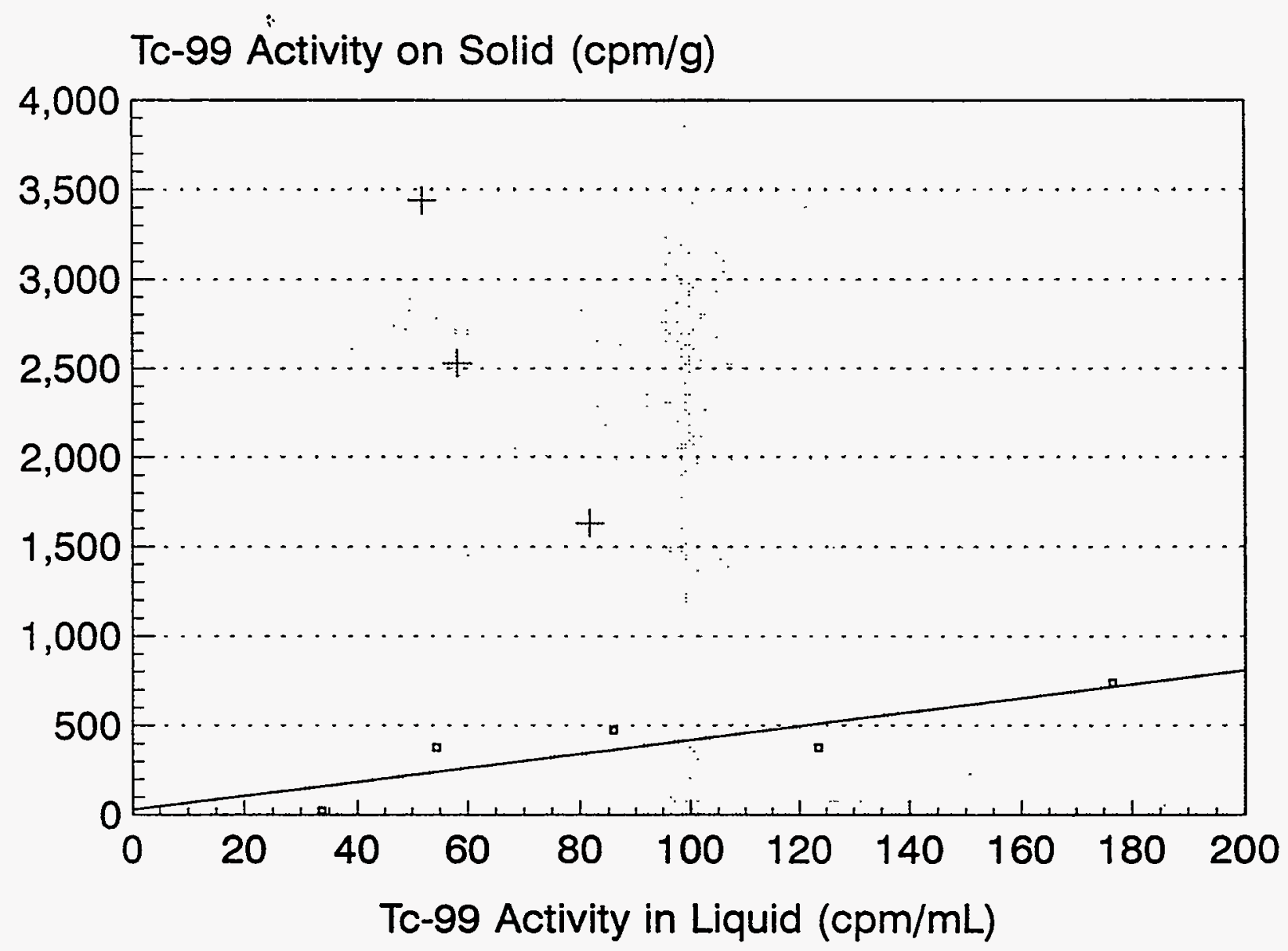

Figure 13 The isotherm for ${ }^{99} \mathrm{Tc}$ is shown along with data from the triplicate batch experiment. While the isotherm has an acceptable fit, with a slope of 3.9 and $\mathrm{R}^{2}$ of 0.74 , the data from the triplicate batch experiment do not fit. This may be the result of changes in sediment chemistry. 


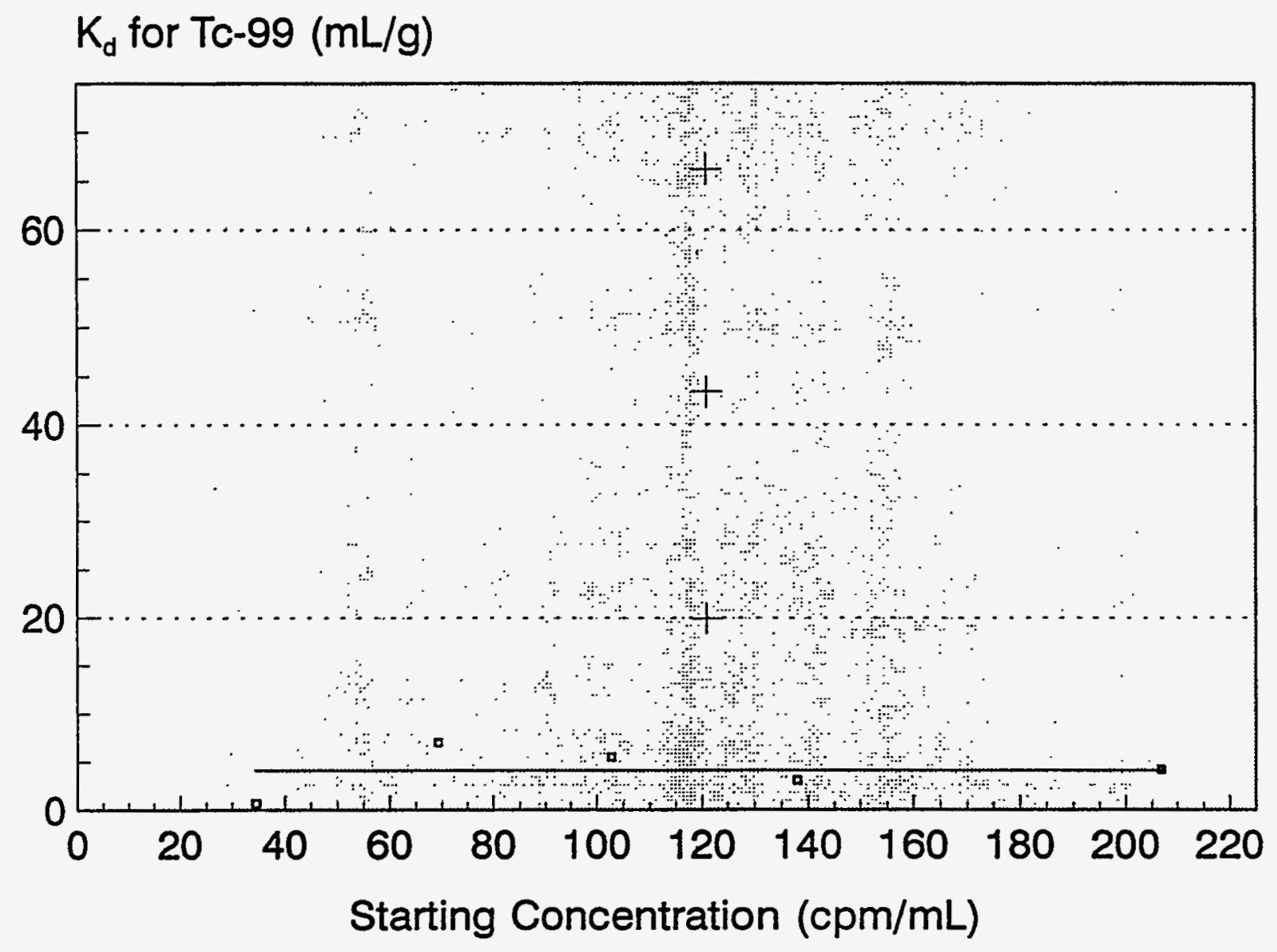

Figure 14 The $\mathrm{K}_{\mathrm{d}}$ values of ${ }^{99} \mathrm{Tc}$ plotted as a function of the starting activity of ${ }^{99} \mathrm{Tc}$ in the contact solution, illustrating the difference between the $K_{d}$ 's of the two experiments. 


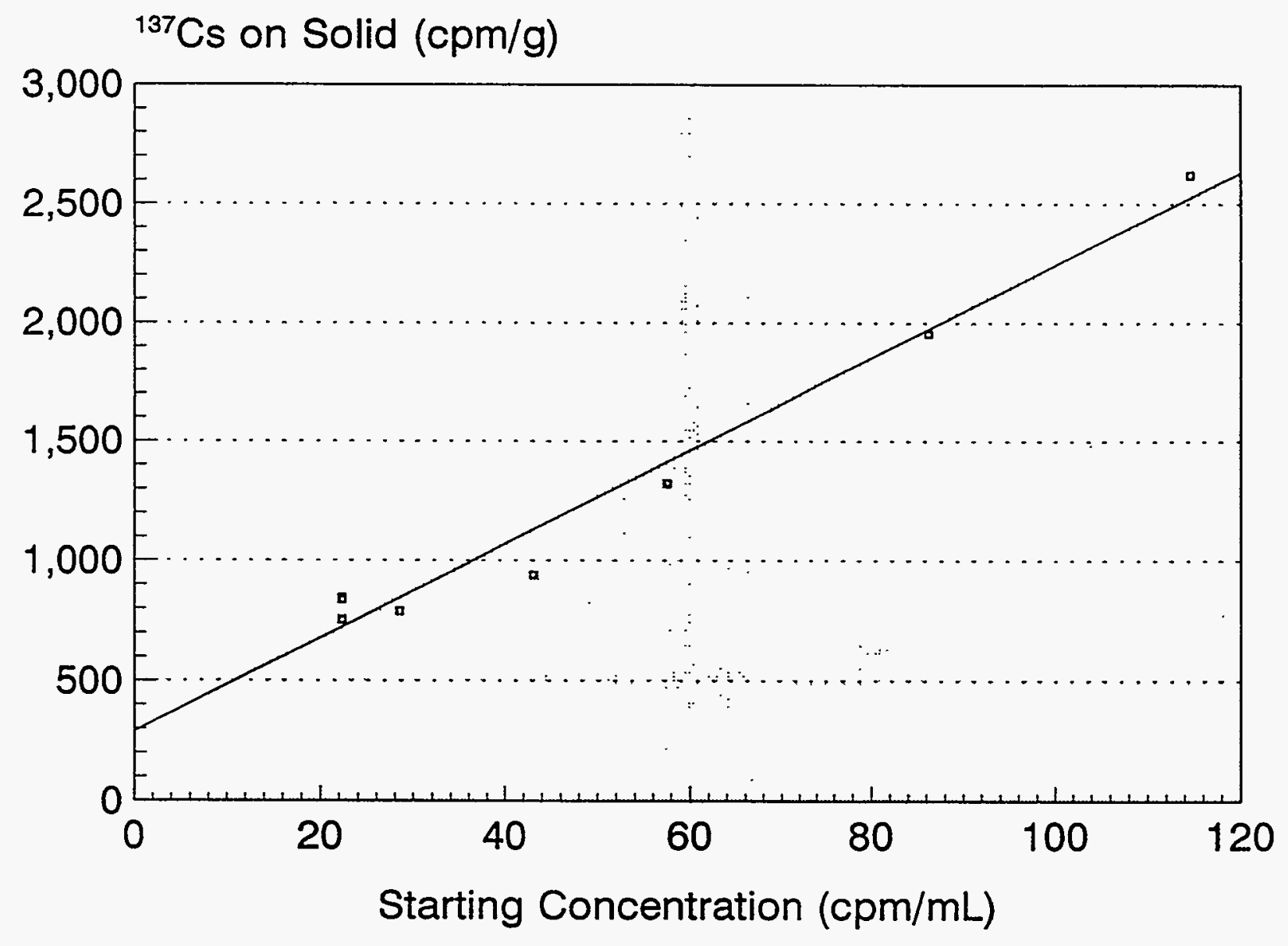

Figure 15 Plotting the activity in solution as a function of the quantity of tracer added gives a determination of the background counts that develop after the contact solution is exposed to the sediment. Projecting the regression line to the $\mathrm{Y}$-axis gives a value of $87.9 \mathrm{cpm}$. 


\section{SORPTION AS A FUNCTION OF LIQUID TO SOLID RATIO}

Another set of experiments examined how the adsorption of $\mathrm{Cs}$ and $\mathrm{Tc}$ are related to the ratio of liquid to solid. This is an important parameter when various scenarios are developed for the way that contaminants are introduced and transported in the marine environment. For example, contaminants have been introduced to the Kara Sea under a variety of conditions which result in very large differences in the amount of sediment that the contaminant is exposed to (and potentially sorbed on) in the near-field of the disposal site. Some of these are illustrated in Figure 16. Simply considering one type of disposal; that of a drum of waste onto the seabed, there are two regimes of liquid to solid ratio (i.e. ratio of seawater to sediment in a volume of material where the release takes place). The contaminant may be released as a solution directly to the seawater above the bottom, in which case the liquid to solid ratio is very large (on the order of $\mathrm{mg} / \mathrm{Kg}$ or $10^{6}$ ). In the other extreme, the container may leak from a corroded area beneath the sediment. In this case the ratio of liquid to solid is quite small (perhaps 0.3 to 0.6 ).

In order to effectively model the near-field impacts of radioactive waste disposal it is necessary to determine if the effects of a varying ratio of liquid to solid can significantly influence sorption of the contaminants. Experiments were conducted to determine if a large difference in liquid to solid ratio can significantly alter the uptake of a set of contaminants. The experiments were batch sorption tests, similar to those described above with 6 and 8 sorption tests conducted for ${ }^{137} \mathrm{Cs}$ and ${ }^{99} \mathrm{Tc}$, respectively.

Figure 17 shows the observed relationship between the amount of ${ }^{137} \mathrm{Cs}$ sorbed on the sediment and the liquid to solid ratio. The slope of this plot is $204\left(R^{2}=0.999\right)$. The mass of ${ }^{137} \mathrm{Cs}$ on each gram of sediment increases in a linear way with increasing liquid to solid ratio. This means that even a very dilute slurry, with respect to solid content, can sorb significant quantities of ${ }^{137} \mathrm{Cs}$, without reducing the proportionality between the mass of ${ }^{137} \mathrm{Cs}$ on the sediment and the mass of ${ }^{137} \mathrm{Cs}$ available (since the amount of $\mathrm{Cs}$ that can be sorbed is directly related to amount of liquid in the experiment).

Figure 18 shows how the mass of ${ }^{99} \mathrm{Tc}$ that is sorbed varies as a function of the liquid to solid ratio. As with ${ }^{137} \mathrm{Cs}$ this is a linear relationship but the slope is lower indicating that changing the liquid to solid ratio has less of an effect on ${ }^{99} \mathrm{Tc}$ than on ${ }^{137} \mathrm{Cs}$. This is a linear relationship. The removal of Tc from solution is very effective, surprising since the pertechnetate anion is generally considered to be very mobile. The experiments were conducted under reducing conditions which may be sufficiently reducing to immobilize $\mathrm{Tc}$ as a reduced oxide $\left(\mathrm{TcO}_{2}\right)$ or as a sulfide. Alternatively it may substitute for iron in reduced iron minerals.

Figure 19 shows how the change in sorption, caused by altering the ratio of liquid to sediment, effects the $K_{D}$ values that are calculated from the sorption data. The $K_{D}$ increases non-linearly with increasing ratio of liquid to solid. Sorption of ${ }^{137} \mathrm{Cs}$ in highly dilute marine systems (such as the case of resuspension of this sediment) will be very great. Figure 19 also shows how $K_{D}$ of ${ }^{99} \mathrm{Tc}$ varies with the ratio of liquid to solid. 


\section{Scenarios for Radionuclide Release from Waste Forms}

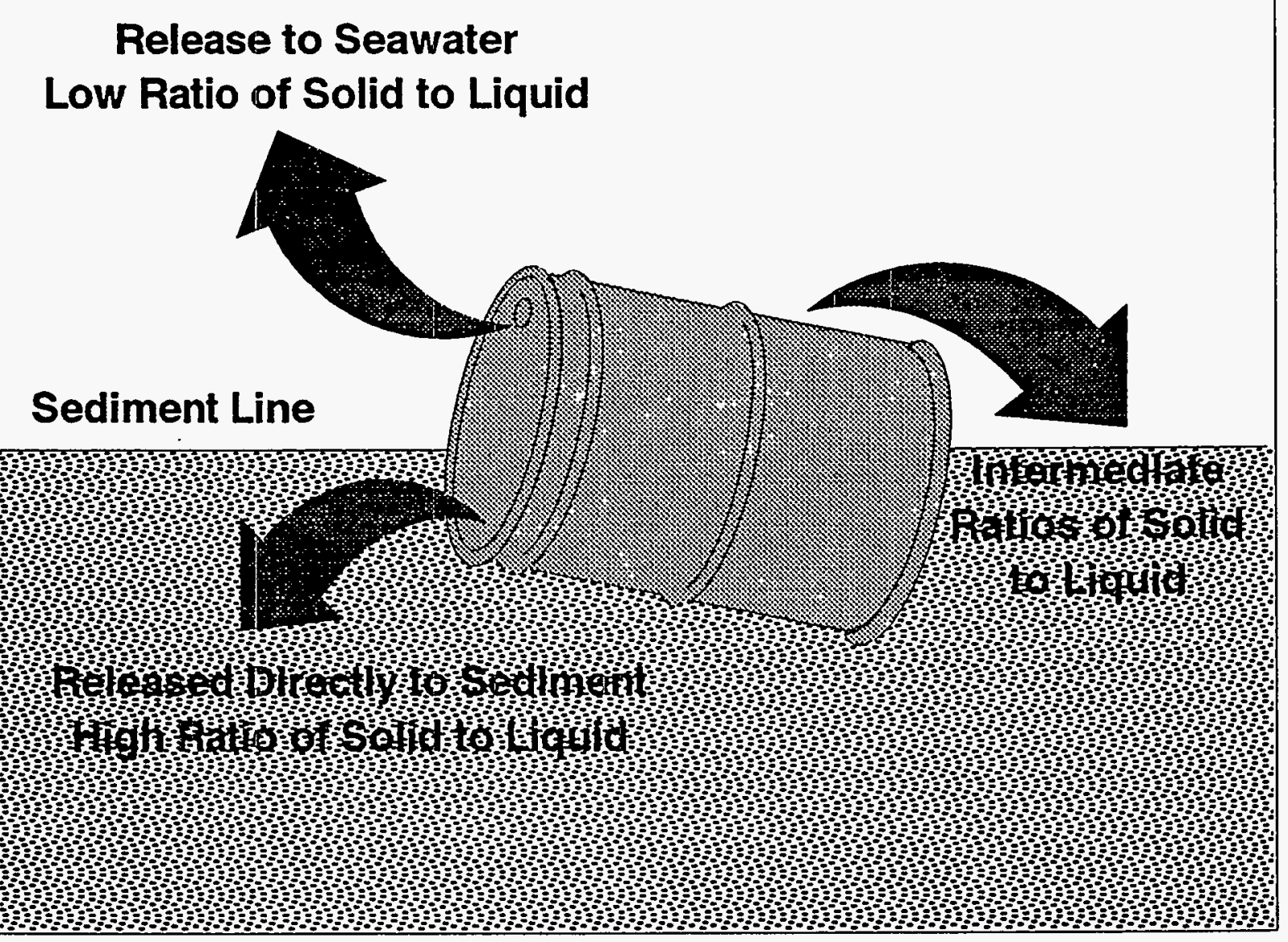

Figure 16 Several scenarios are illustrated for the release of radioactive liquid from a waste container. Each scenario can differ greatly in the ratio of liquid to solid to which the contaminant is exposed in the near field. 


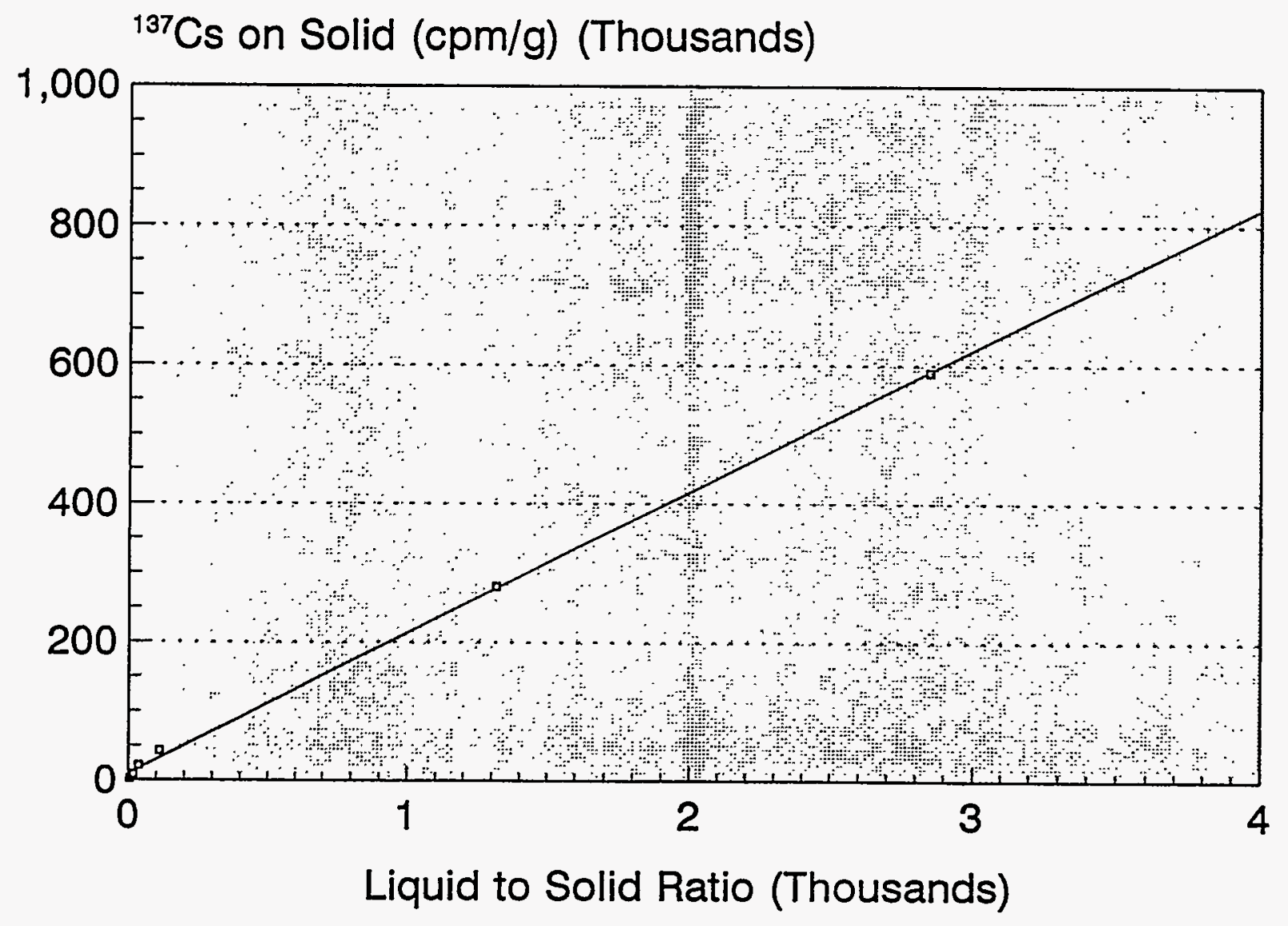

Figure 17 The relationship between the uptake of ${ }^{137} \mathrm{Cs}$ and the liquid to solid ratio is linear with a slope of 204 and $R^{2}$ of 0.999 . 


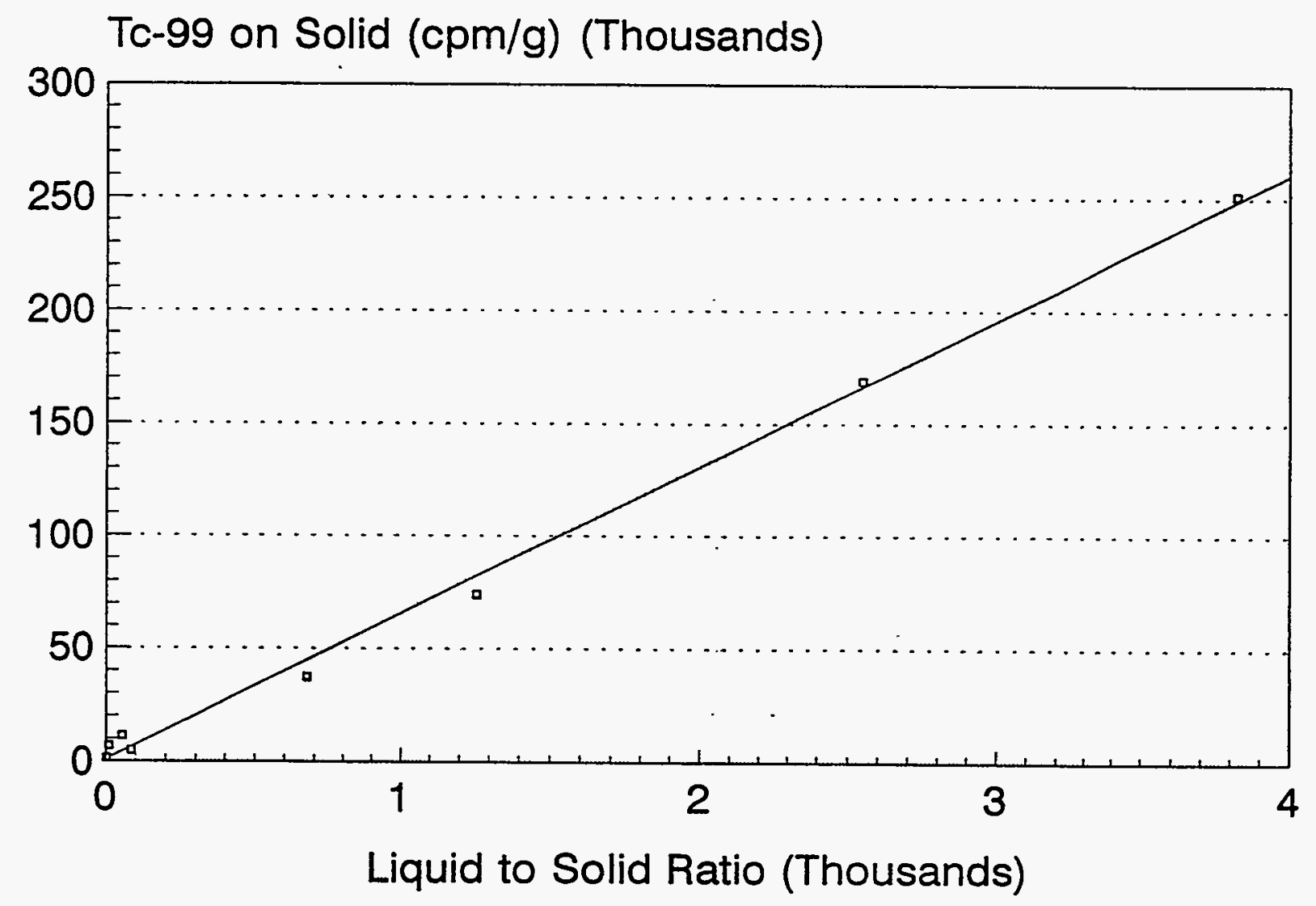

Figure 18 The relationship between the uptake of ${ }^{99} \mathrm{Tc}$ and the liquid to solid ratio is linear. 


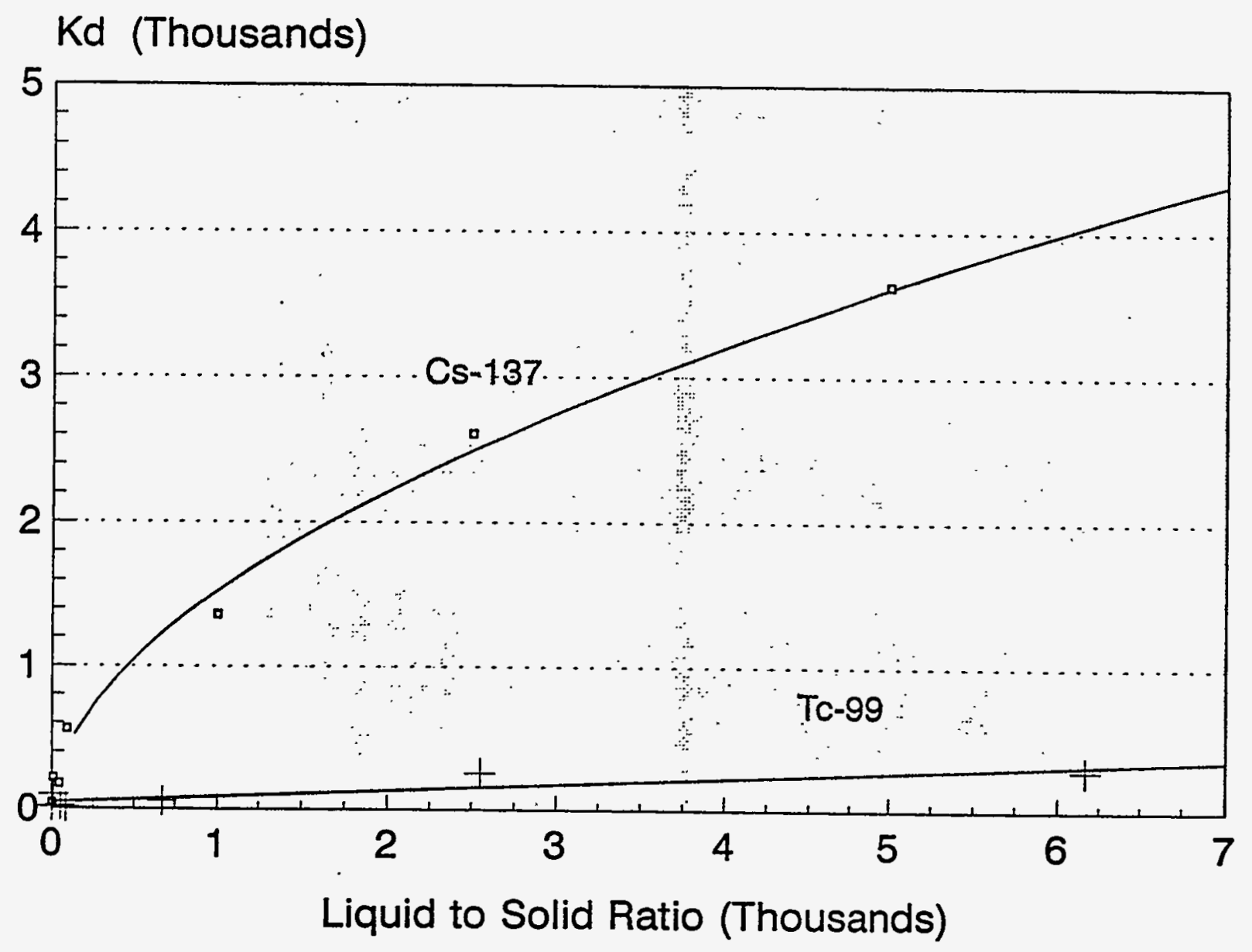

Cs-137 Power Regression: $\ln y=3.62+0.54 \ln x$ Tc-99 Linear Regression: $y=0.044 x+43.9$

Figure $19 \quad \mathrm{~K}_{\mathrm{d}}$ values determined for ${ }^{137} \mathrm{Cs}$ and ${ }^{99} \mathrm{Tc}$ are affected differently by changing the liquid to solid ratio. 
In the literature, a number of examples have been identified in which sorption of contaminants has shown an inverse proportionality between the $\mathrm{K}_{\mathrm{d}}$ and the mass of solid in the experimental system. Most of this work focuses on hydrophobic organic liquids but some of it examined metal sorption [McKinley and Jenne, 1991; Honeyman and Santschi, 1988; DiToro et al, 1986]. This has been called the "solids concentration" effect. Voice et al [1983] suggested that this effect for hydrophobic organic liquids is caused by the presence of microparticles and associated organic carbon remaining in suspension after the separation process. Gschwend and Wu [1985] demonstrated that the quantity of non-settling particles (NSP) or macroparticles (as measured by weight of dissolved solids) was proportional to the solid-to-liquid ratio; concluding that any observed change in $\mathrm{K}_{\mathrm{d}}$ as a function of liquid-to-solid ratio is an experimental artifact caused by incomplete phase separation. For hydrophobic organic liquids they developed a three "phase" model that includes the dissolved phase, the material sorbed on settling particles and on non-settling particles. Although the literature focuses on organic liquids some of the issues, such as incomplete phase separation, are equally relevant to metals.

McKinley and Jenne [1991] reviewed the literature and performed a set of experiments examining the sorption of $\mathrm{Cd}$ on iron oxyhydroxide. They grouped the causes of the "solid concentration" effect as:

1. sorption by non-settling (or unfilterable) colloids that remain in suspension after separation processes,

2. competition for the species being sorbed by complexing agents (e.g. organic carbon) being released from the solid phase,

3. competition by other sorbing species,

4. increased aggregation of solids resulting in reduced numbers of sorption sites,

5. chemical reactions such as dissolution of sulfide minerals or precipitation of metal oxyhydroxides, as well as reactions caused by bacterial activity resulting in changes in $\mathrm{pH}$ or Eh.

Their experimental results indicate that the $\mathrm{K}_{\mathrm{d}}$ for $\mathrm{Cd}$ is constant at constant $\mathrm{pH}$ and equilibrium concentration of $\mathrm{Cd}$ in solution even though the mass of solid was varied.

In our study the "solids concentration" effect has significant control over the $\mathrm{K}_{\mathrm{d}}$ for ${ }^{99} \mathrm{Tc}$ and ${ }^{137} \mathrm{Cs}$. Depending on the cause of this effect for the Kara Sea sediment, there may be significant impact on the transport of radionuclides in the marine environment. Several of the causes that are described above can be eliminated from consideration because the experiments were conducted in seawater. Since seawater is a relatively high ionic strength solution, it readily floculates particles. This should significantly reduce the concentration of colloidal particles that cannot be filtered. In addition the seawater will buffer the $\mathrm{pH}$ of the system. Our experiments used single isotope tracers and therefore there were no other sorbing species to compete with the tracer other than those that may have been in contact with the sediment under natural conditions, specifically, stable Cs in the seawater. For ${ }^{99} \mathrm{Tc}$ the issue is less clear, depending on its speciation. While there would be no direct competition from natural Tc (it does not exist 
except in very rare cases) there may be competition from other oxyanions, since Tc is probably present in solution as $\mathrm{TcO}_{4}$.

To explore this issue further, additional experimental work is recommended to try to determine the specific causes of the "solids concentration" effect on the Kara Sea sediment. This work could include:

1. a series of filtrations with different pore size filters down to $0.01 \mu \mathrm{m}$.

2. the sediment/water system could be poisoned to eliminate effects of bacterial activity.

3. the quantity of dissolved organic carbon released to solution by different masses of sediment could be compared to the change in $K_{d}$ that is observed for different radionuclides.

\section{SORPTION ON DIFFERENT SIZE FRACTIONS OF THE SEDIMENT}

Experiments to assess the distribution coefficients for ${ }^{137} \mathrm{Cs},{ }^{85} \mathrm{Sr}$ and ${ }^{99} \mathrm{Tc}$ on different size fractions of sediment from the Kara Sea were conducted. The sediment was separated into 4 fractions under an argon atmosphere. This was necessary to prevent the material from oxidizing. The sediment was wet sieved to first separate the $>45 \mu \mathrm{m}$ fraction. Then the sediment slurry (produced with distilled water and no dispersant) was further separated by pipette using time intervals calculated to give fractions of $<10 \mu \mathrm{m}$ (16.7 minutes) and $<4 \mu \mathrm{m}$ (98 minutes). After the 10 and $4 \mu \mathrm{m}$ fractions were withdrawn, the remaining slurry was collected as the $10-45 \mu \mathrm{m}$ fraction. These four separated slurries were centrifuged and decanted. The water content was determined for each by drying subsamples at $60^{\circ} \mathrm{C}$, so that the mass of sediment in each experiment could be normalized. The fractions and their water content were:

1. greater than 45 micrometers $-16.6 \%$ water

2. $10-45$ micrometers $-47.3 \%$ water

3 . less than 10 micrometers $-51.5 \%$ water

4. less than 4 micrometers $-52.8 \%$ water.

These size ranges conform to those samples that were analyzed, earlier, for mineralogy. Samples of the wet sediment fractions (equivalent to about $0.5 \mathrm{~g}$ dry weight) were weighed into plastic centrifuge tubes and transferred to a glove box (also containing an argon atmosphere) where sea water that contained the individual radioactive tracers was added. The seawater had previously been boiled to purge it of any oxygen.

Results are shown in Figures 20a, 21a, and 22a as the percentage of the activity that was sorbed relative to the activity that was originally in the contact solution and in Figures 20b, 21b, and $22 \mathrm{~b}$ as the $\mathrm{K}_{\mathrm{d}}$ calculated from the experimental data. Results are also presented in Table 6 in which the Kd values for each size fraction are given. 


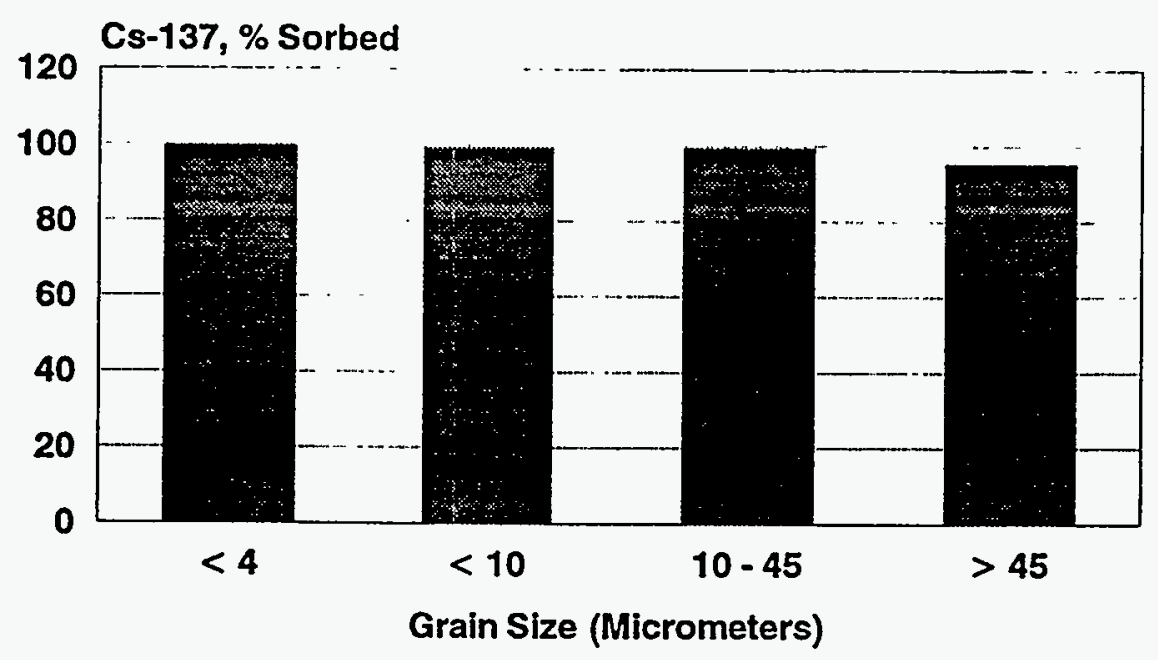

Figure 20a The percentage of ${ }^{137} \mathrm{Cs}$ sorbed on each of four size fractions is shown on the histogram. The percentage is calculated relative to the starting activity in the contact solution of each size fraction.

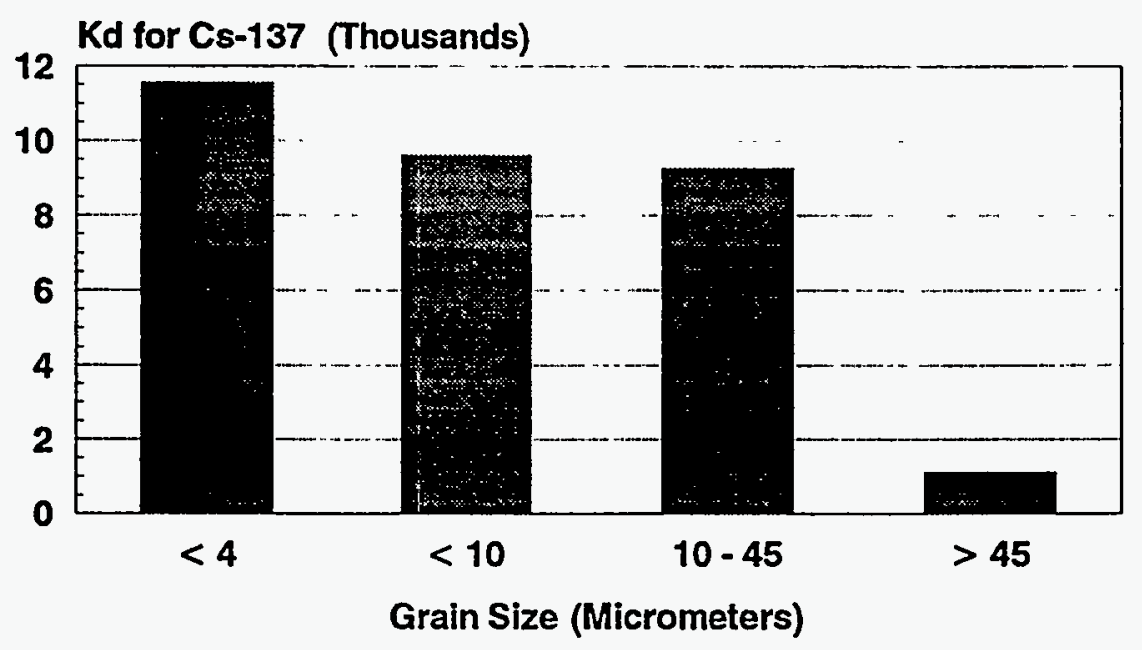

Figure $20 \mathrm{~b} \quad \mathrm{~K}_{\mathrm{d}}$ values for ${ }^{137} \mathrm{Cs}$ were determined for each of the four size fractions. 


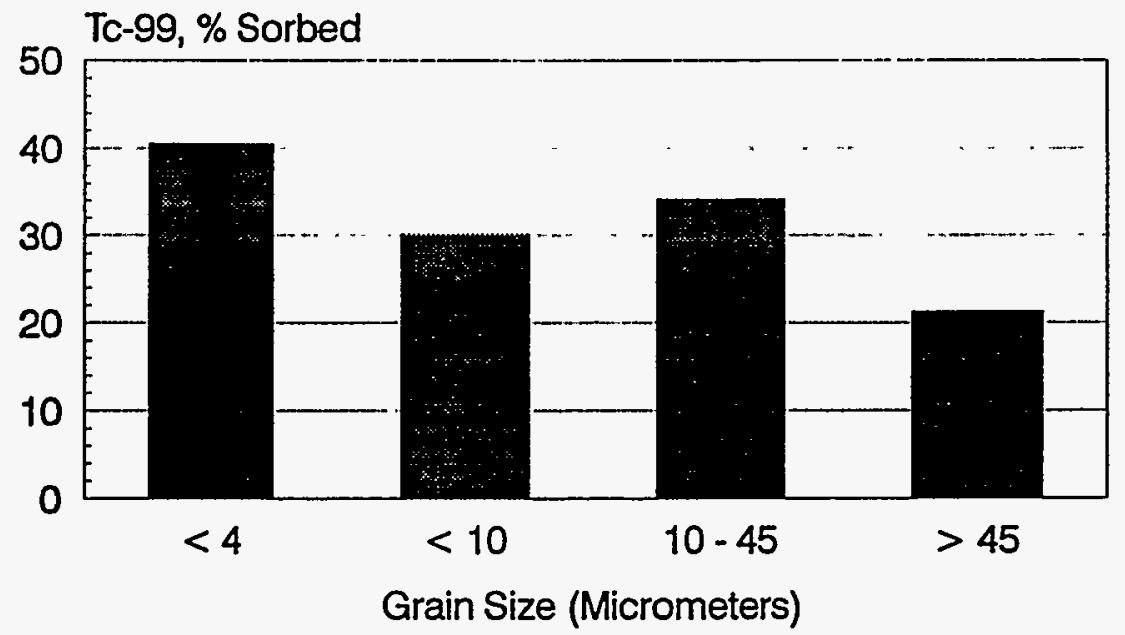

Figure 21a The percentage of ${ }^{99} \mathrm{Tc}$ sorbed on each of four size fractions is shown on the histogram. The percentage is calculated relative to the starting activity in the contact solution of each size fraction.

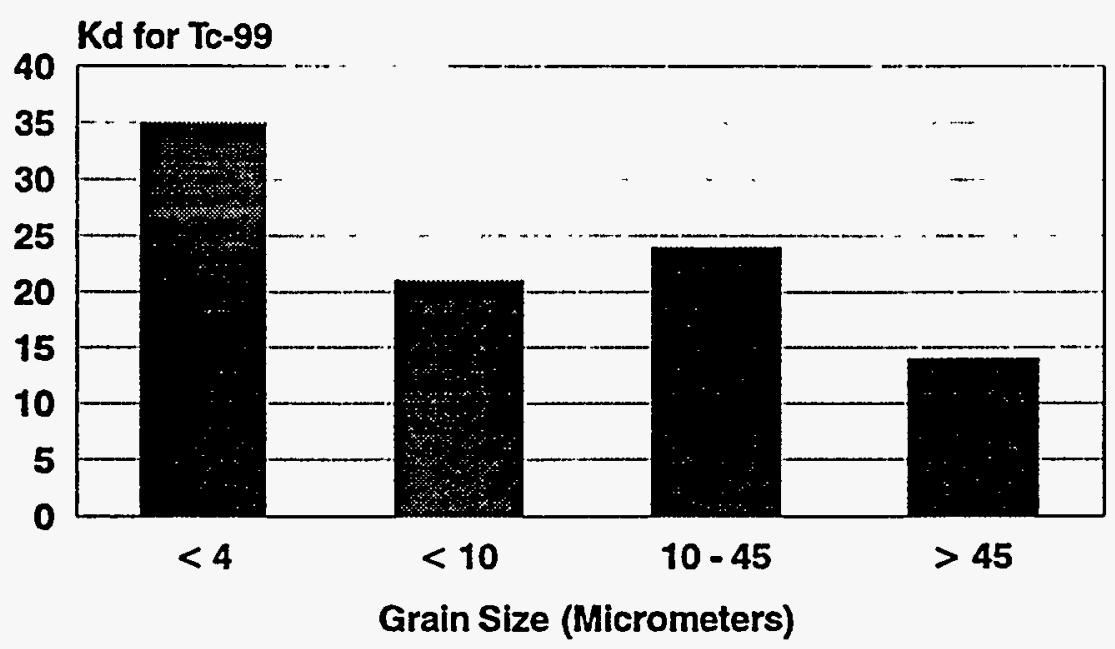

Figure 21b $\quad K_{d}$ values for ${ }^{99} \mathrm{Tc}$ were determined for each of the four size fractions, with the finest fraction having a significantly higher $\mathrm{K}_{\mathbf{d}}$. 


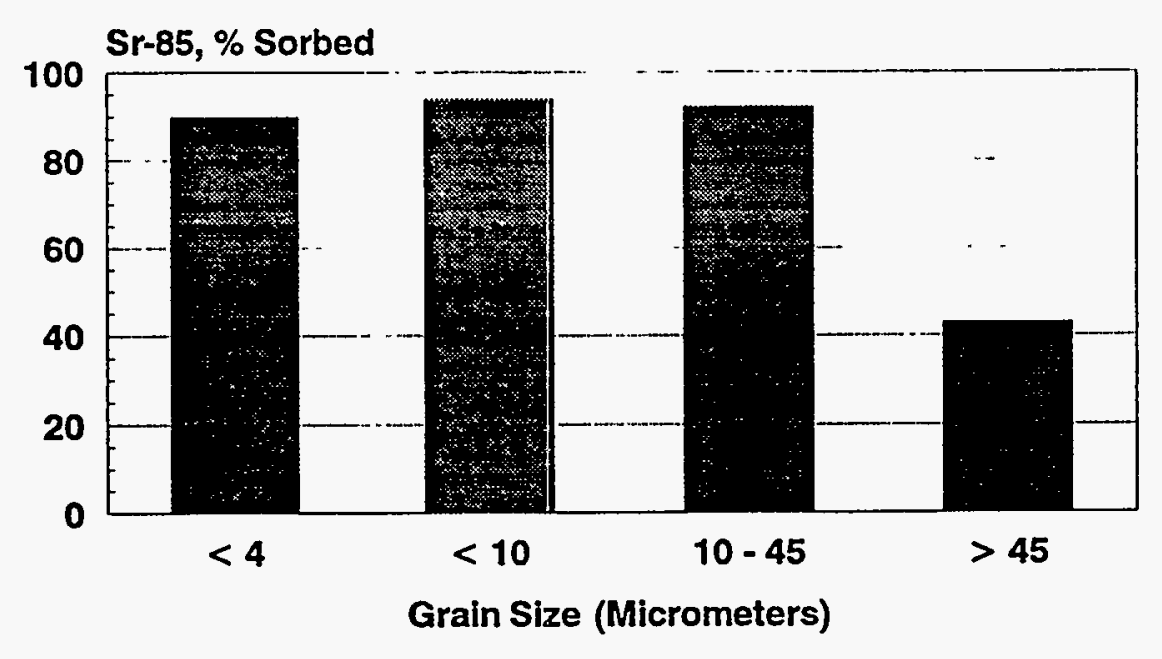

Figure 22a The percentage of ${ }^{85} \mathrm{Sr}$ sorbed on each of four size fractions is shown on the histogram. The percentage is calculated relative to the starting activity in the contact solution of each size fraction.

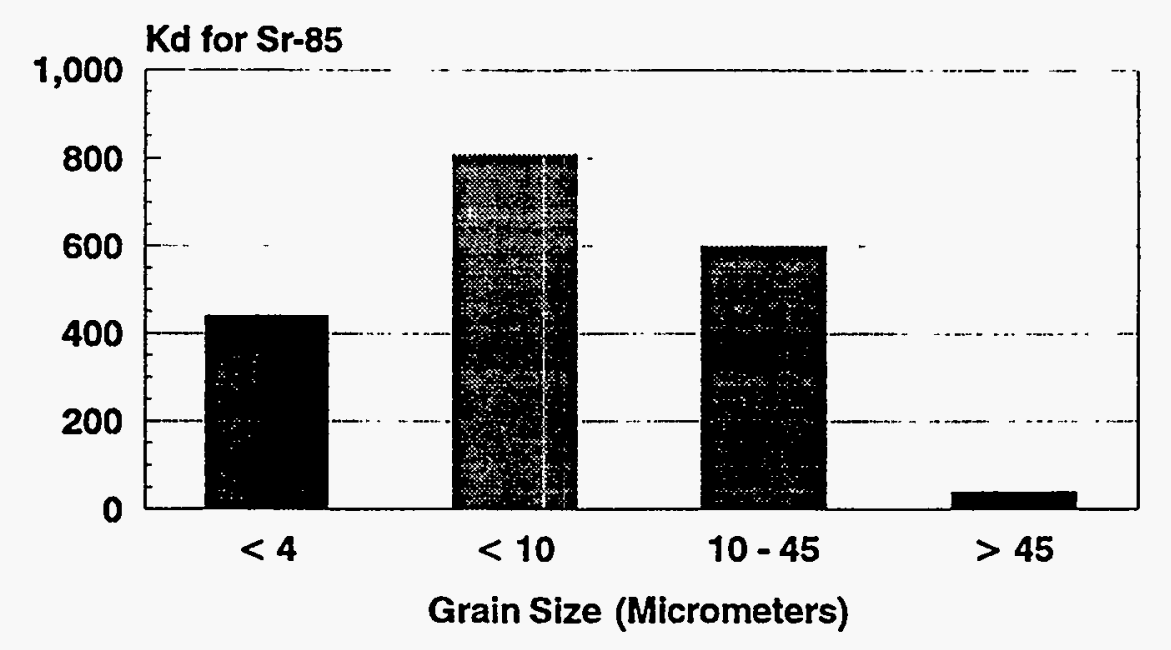

Figure 22b $\quad \mathrm{K}_{d}$ values for ${ }^{85} \mathrm{Sr}$ were determined for each of the four size fractions, with the two intermediate size fractions having higher $\mathrm{K}_{d}$ values. This is an artifact of small differences in the activity remaining in the liquid affecting the $K_{d}$ value. 
Most of the ${ }^{137} \mathrm{Cs}$ was sorbed by the sediment, with the coarse fraction taking up only slightly less than the finer grained fractions. The $K_{d}$ values are a more sensitive indicator of uptake than the quantity sorbed per gram of solid. There are no statistically significant differences among the $<4,<10$ and 10-40 micron fractions. Every fraction sorbed essentially identical quantities of ${ }^{137} \mathrm{Cs}$. In this case, because almost all of the ${ }^{137} \mathrm{Cs}$ was sorbed, the value of $K_{d}$ calculated from this data changes significantly with only a very small change of the activity in the liquid.

Uptake of ${ }^{99} \mathrm{Tc}$ varied by a factor of 2 between the finest and coarsest fractions, with from about $40 \%$ to $21 \%$ sorbed, as shown in Figures $21 \mathrm{a}$ and $\mathrm{b}$. The increase in sorption of the 10-40 micron fraction over that of the $<10$ micron fraction is statistically significant and may represent an effect of differences in mineralogy between the two samples. Values of $K_{d}$ varied in a similar manner.

Sorption of ${ }^{85} \mathrm{Sr}$, Figures $22 \mathrm{a}$ and $\mathrm{b}$, resulted in essentially the same quantity of $\mathrm{Sr}$ retained on each gram of sediment. As with Cs the activity that remains in the liquid controls the $\mathrm{K}_{\mathrm{d}}$ value. The counting errors are around $4 \%$ for each measurement. Therefore the activity in the liquid phase is not statistically different among the samples of the three finer grained materials. The coarsest fraction sorbed only about one half the ${ }^{85} \mathrm{Sr}$ that the finer fractions sorbed.

Overall there is relatively little difference, if any, in sorption among the three finer grained fractions. The coarsest fraction did have significantly lower uptake for all three tracers, as one would expect. In comparing the $\mathrm{K}_{\mathrm{d}}$ values obtained for this set of experiments with the values in Table 4, there are large differences, with the values from this experiment being much higher. There are several possible explanations for this. The first is that there has been some alteration of the sediment over the coarse of this project. The material has been stored in a glove box under argon, but occasionally the flow of argon has been interrupted and air probably found its way into the box. Although the samples were in bottles, some oxidation did take place on the surface of some of the material. We were able to use sediment that appeared to be little altered by oxidation, based on color. Since the isotherm experiments were done after these experiments, with results that generally compare favorably with the earlier values obtained in the batch $\mathrm{K}_{\mathrm{d}}$ experiments, this indicates that there has been little change of the sediment over time.

A second possibility is more likely the cause of the observed differences. In order to separate the size fractions of the sediment, the material was suspended in de-aired distilled water. It was then wet sieved and separated by settling. After centrifuging and decanting the liquid, the sediment was re-exposed to seawater. It may be that this process altered the chemistry of the mineral surfaces sufficiently that its ability to sorb tracers was enhanced. Another effect of the suspension in distilled water is that agglomerated particles would be dispersed as they are exposed to a low ionic strength solution. Even though they were placed back into seawater there may have been some residual changes. 
Table 6

Effect of Grain Size On Kd for Cs, Tc and Sr

\begin{tabular}{||c|c|c|c|c|c|c||}
\hline Sample & $\begin{array}{c}\text { Sediment } \\
\text { Dry Wt. } \\
\text { (g) }\end{array}$ & $\begin{array}{c}\text { Total } \\
\text { Liquid } \\
\text { (g) }\end{array}$ & $\begin{array}{c}\text { Activity } \\
\text { in Liquid } \\
\text { (cpm/mL) }\end{array}$ & $\begin{array}{c}\text { Activity } \\
\text { on Solid } \\
\text { (cpm/g) }\end{array}$ & $\begin{array}{c}\text { \% } \\
\text { Sorbed }\end{array}$ & $\begin{array}{c}\text { Kd } \\
\text { (mL/g) }\end{array}$ \\
\hline Cs $<4$ & 0.505 & 25.63 & 0.11 & 1238 & 99.6 & 11600 \\
\hline Cs $<10$ & 0.500 & 25.63 & 0.13 & 1250 & 99.5 & 9620 \\
\hline Cs 10-45 & 0.506 & 25.45 & 0.13 & 1226 & 99.5 & 9280 \\
\hline Cs $>45$ & 0.475 & 25.24 & 1.16 & 1240 & 95.3 & 1070 \\
\hline Cs Ref & 0 & --- & 24.50 & -- & -- & -- \\
\hline \hline Tc <4 & 0.510 & 26.17 & 97.0 & 3390 & 40.5 & 35 \\
\hline Tc < 10 & 0.538 & 26.18 & 113.7 & 2398 & 30.3 & 21 \\
\hline Tc 10-45 & 0.559 & 25.95 & 107.3 & 2589 & 34.2 & 21 \\
\hline Tc $>45$ & 0.500 & 25.66 & 128.3 & 1777 & 21.3 & 14 \\
\hline Tc Ref & 0 & --- & 163.0 & -- & -- & -- \\
\hline \hline Sr $<4$ & 0.510 & 25.47 & 1.39 & 608 & 89.8 & 440 \\
\hline Sr $<10$ & 0.509 & 25.77 & 0.80 & 646 & 94.1 & 810 \\
\hline Sr 10-45 & 0.501 & 25.33 & 1.06 & 633 & 92.2 & 600 \\
\hline Sr $>45$ & 0.475 & 25.09 & 7.74 & 307 & 42.9 & 40 \\
\hline Sr Ref & 0 & -- & 13.56 & --- & & -- \\
\hline
\end{tabular}




\section{RADIONUCLIDES ON THE SEDIMENT}

The core was sectioned into specimens that were sent to Lockheed Environmental Systems and Technologies, Las Vegas, for radiochemical analysis. The matrix blank values on some of the analyses where slightly elevated. However, there was insufficient sample volume and time to rerun the analyses to verify that samples were free from contamination. All sample activity was corrected to August 6,1993. Positions of the samples and their weights are listed in Table 7. Results are summarized in Table 8 for all radionuclides analyzed. Table 9 gives the results for $\mathrm{Pu}-239 / 240$ in the sections where it was detected.

\section{Pu-238 and Pu-239/40}

Each sample of dried, homogenized sediment was dissolved using microwave digestion. The isotopic plutonium analysis was performed using LAL-91-SOP-0 108 . This is a sequential ion exchange separation of actinide elements, followed by microprecipitation and alpha spectroscopy. Plutonium-242 was used for a yield tracer with Pu-239 used for the matrix spikes and laboratory control samples.

\section{$P u$ Evaluation}

The sample was analyzed in batch Rl 08Q-1 9. The matrix blank Pu-239/40 value was above the reporting detection limit (RDL), and may be a significantly contributing factor to Section 3 and 4 samples, which were not more than five times the activity of the matrix blank. The Pu-239 laboratory control sample (LCS) recovery was within limits. No duplicates were run due to lack of sufficient sample. All the samples had activity detected above the RDL of $0.01 \mathrm{~Bq} / \mathrm{kg}$.

\section{Am-241}

The isotopic americium analysis was performed using LAL-91-SOP-0 108 as described above. This was followed by a solid phase extraction of the americium, followed by microprecipitation and alpha spectroscopy. Am-243 was used as a yield tracer.

\section{Am-241 Evaluation}

The samples were analyzed in batch $\mathrm{R} 108 \mathrm{~B}-15$. The matrix blank value was above the RDL, and may be a significantly contributing factor to all samples, which were not more than five times the activity of the matrix blank. The LCS recovery was within limits. No duplicates were run due to lack of sample. All the samples had activity detected above the RDL of $0.01 \mathrm{~Bq} / \mathrm{kg}$; however, this activity is not significantly different than the matrix blank.

\section{Sr total}

The strontium analysis was performed using LAL-91 -SOP-01 96. This is an ion exchange separation followed by a strontium specific solid phase extraction. The strontium is evaporated onto a planchet and counted by gross beta gas proportional counting. Elemental strontium is used for yield tracing. 


\section{Total Sr Evaluation}

The samples were analyzed on batch $\mathrm{Rl} 96 \mathrm{~S}-6$. There were no problems encountered during analysis. No duplicates were run due to lack of sample. The LCS and matrix blank data were within limits. The samples did not contain any activity detectable above the RDL of $20 \mathrm{~Bq} / \mathrm{kg}$.

\section{Gamma Spectrum Analysis}

Gamma spectrum analysis was performed using LAL-91 -SOP-0064, which is a gamma prep and counting procedure. There were no problems encountered during analysis. All QC data were within limits. 
Table 7

Depth and Weights of Specimens for Radiochemical Analysis

\begin{tabular}{||c||c|c|c|c||}
\hline \hline Section & $\begin{array}{c}\text { Depth } \\
\text { (cm) }\end{array}$ & $\begin{array}{c}\text { Wet Weight } \\
\text { (g) }\end{array}$ & $\begin{array}{c}\text { Dry Weight } \\
\text { (g) }\end{array}$ & $\begin{array}{c}\text { Water Content } \\
\text { (\%) }\end{array}$ \\
\hline 1 & $0-3$ & 25.831 & 14.12 & 45.3 \\
\hline 2 & $3-6$ & 25.698 & 14.21 & 44.7 \\
\hline 3 & $6-9$ & 41.176 & 22.79 & 44.6 \\
\hline 4 & $9-12$ & 43.469 & 24.60 & 43.4 \\
\hline 5 & $12-15$ & 45.457 & 25.58 & 43.7 \\
\hline 6 & $15-18$ & 46.591 & 26.13 & 43.9 \\
\hline 7 & $18-21$ & 48.498 & 27.18 & 43.9 \\
\hline 8 & $21-24$ & 50.700 & 29.26 & 42.3 \\
\hline 9 & $24-27$ & 46.845 & 26.95 & 42.5 \\
\hline 10 & $27-32$ & 43.195 & 26.60 & 38.4 \\
\hline
\end{tabular}


Table 8

Radionuclide Analysis of Sediment

From the Kara Sea

\begin{tabular}{|c|c|c|}
\hline \multirow{2}{*}{ RADIONUCLIDE } & $\begin{array}{c}\text { OBSERVATION } \\
(\mathrm{Bq} / \mathrm{Kg})\end{array}$ & MINIMUM DETECTABLE ACTIVIT** \\
\hline MANGANESE-54 & BDL & 3.1 \\
\hline COBALT-60 & BDL & 3.4 \\
\hline RUTHENIUM-106 & BDL & 33.2 \\
\hline CESIUM-134 & BDL & 6.3 \\
\hline CESIUM-137 & BDL & 4.0 \\
\hline STRONTIUM-90 & BDL & 8.9 \\
\hline AMERICIUM-241 & 0.031 to 0.038 & 0.008 \\
& BDL & (Method Blank $=0.030)$ \\
\hline PLUTONIUM-238 & 0.420 to 0.196 & 0.036 \\
\hline PLUTONIUM-239/240 & & 0.007 \\
\hline
\end{tabular}

$* \mathrm{~Bq} / \mathrm{Kg}$ for the first 3 downcore sections.

Analysis performed by Lockheed Environmental Systems and Technologies Co. 
Table 9

Plutonium - 239/240 Activity in a Sediment Sample From the Kara Sea

\begin{tabular}{|c|c|c|c|c|}
\hline $\begin{array}{c}\text { SAMPLE } \\
\text { DEPTH (CM) }\end{array}$ & $\begin{array}{c}\text { WEIGHT } \\
\text { DRY (g) }\end{array}$ & $\begin{array}{c}\text { ACTIVITY } \\
(\mathrm{Bq} / \mathrm{Kg})\end{array}$ & $\begin{array}{c}\text { ERROR* } \\
(\mathrm{Bq} / \mathrm{Kg})\end{array}$ & $\begin{array}{c}\text { MDA** } \\
(\mathrm{Bq} / \mathrm{Kg})\end{array}$ \\
\hline $0-3$ & 12.43 & 0.420 & 0.080 & 0.009 \\
\hline $3-6$ & 12.14 & 0.395 & 0.076 & 0.009 \\
\hline $6-9$ & 20.12 & 0.196 & 0.040 & 0.005 \\
\hline $9-12$ & 20.04 & 0.222 & 0.043 & 0.005 \\
\hline MBB*** & 20.0 & 0.061 & 0.023 & 0.020 \\
\hline LCS**** & 20.0 & 4.413 & 0.368 & 0.024 \\
\hline
\end{tabular}

* 2 Sigma Total Propagated Error

** MINIMUM DETECTABLE ACTIVITY, by method of L.A. Currie.

*** Method Blank

**** Lab Control Sample, true value $=4.285 \mathrm{~Bq} / \mathrm{Kg}($ recovery $=103 \%)$ 


\section{CONCLUSIONS}

The mean grain size of a surface sample was 17 microns (sand $=7.5 \%$, silt $=71.5 \%$ and clay $=21 \%$ ) the total organic carbon (TOC) was $93 \mathrm{mg} / \mathrm{g}$ in the $0-6 \mathrm{~cm}$ fraction and 80 $\mathrm{mg} / \mathrm{g}$ in the $26-28 \mathrm{~cm}$ fraction. Mineralogy of the sample was dominated by quartz and feldspar in the sand and coarse silt fractions and by illite/mica, chlorite and kaolinite in the fine silt. The clay fraction was comprised primarily of mixed layer smectite $(34 \%)$, illite $(18 \%)$, chlorite (17\%) and kaolinite (14\%).

Uptake kinetics were determined for ${ }^{85} \mathrm{Sr},{ }^{99} \mathrm{Tc},{ }^{125} \mathrm{I},{ }^{137} \mathrm{Cs},{ }^{210} \mathrm{~Pb},{ }^{232} \mathrm{U}$, and ${ }^{241} \mathrm{Am}$. Slow kinetics were observed for uranium and technetium implying that the rate limiting process was probably not adsorption but a reaction prior to uptake. Distribution coefficients were determined for six of these radionuclides ( $\mathrm{Pb}$ was excluded) using batch type experiments. In addition the $\mathrm{K}_{\mathrm{d}}$ values for ${ }^{137} \mathrm{Cs}$, ${ }^{85} \mathrm{Sr}$ and ${ }^{99} \mathrm{Tc}$ were also determined using isotherms. The isotherms for Cs, $\mathrm{Sr}$ and, to a lesser extent, Tc were linear indicating that it is appropriate to use the $\mathrm{K}_{d}$ determined with higher activity tracers to those activities encountered in the environment. For the batch tests and the isotherms the $\mathrm{K}_{\mathbf{d}}$ values were:

\begin{tabular}{|c|c|}
\hline Uranium & $\begin{array}{l}\text { Slow Kinetics } \\
\mathrm{K}_{\mathrm{d}}=23 \mathrm{~mL} / \mathrm{g} \text { (batch) }\end{array}$ \\
\hline Lead & $\begin{array}{l}\text { Rapid Kinetics } \\
\text { All Pb Removed From Solution (batch) }\end{array}$ \\
\hline Cesium & $\begin{array}{l}\text { Rapid Kinetics } \\
\mathrm{K}_{\mathrm{d}} \text { varies with Solid:Liquid, } \\
\mathrm{K}_{\mathrm{d}}=230 \text { (batch), } \mathrm{K}_{\mathrm{d}}=360 \text { (isotherm }\end{array}$ \\
\hline Strontium & $\begin{array}{l}\text { Rapid Kinetics } \\
\mathrm{K}_{\mathrm{d}}=5.3 \text { (batch), } \mathrm{K}_{\mathrm{d}}=3.2 \text { (isotherm) }\end{array}$ \\
\hline Iodine & $\begin{array}{l}\text { Slow Kinetics } \\
\mathrm{K}_{\mathrm{d}}=56 \text { (batch) }\end{array}$ \\
\hline Technetium & $\begin{array}{l}\text { Slow Kinetics } \\
\mathrm{K}_{\mathrm{d}}=43 \text { (batch), } \mathrm{K}_{\mathrm{d}}=3.9 \text { (isotherm) }\end{array}$ \\
\hline Americium & $\begin{array}{l}\text { Very Rapid Kinetics } \\
\mathrm{K}_{d}=5600 \text { or greater (batch) }\end{array}$ \\
\hline
\end{tabular}

The $\mathrm{K}_{\mathrm{d}}$ values of ${ }^{99} \mathrm{Tc}$ and ${ }^{137} \mathrm{Cs}$ are influenced by the solid to liquid ratio. While in a laboratory experiment with simple materials (e.g. single minerals in a contact solution of simple chemistry) there should be no effect; in a natural system (or at least using complex natural materials) we 
observed that the $\mathrm{K}_{\mathrm{d}}$ for ${ }^{137} \mathrm{Cs}$ varied nonlinearly from 40 to $3600 \mathrm{~mL} / \mathrm{g}$ as the liquid to solid ratio varied from 3.4 to 6400 .

The sediment was separated into four size fractions ( $>45 \mu \mathrm{m}, 10-45 \mu \mathrm{m},>10 \mu \mathrm{m}$ and $>4 \mu \mathrm{m})$ and uptake was determined for each fraction for ${ }^{137} \mathrm{Cs},{ }^{85} \mathrm{Sr}$ and ${ }^{99} \mathrm{Tc}$. Overall there is relatively little difference, if any, in sorption among the three finer grained fractions. The coarsest fraction did have significantly lower uptake for all three tracers, as one would expect. In comparing the $\mathrm{K}_{\mathrm{d}}$ values obtained for this set of experiments with the values in Table 4, there are large differences, with the values from this experiment being much higher. The likely explanation for this effect is the grain size separation process resulted in desorption of trace metals and deflocculation of mineral grains giving the sediment greater surface area and capacity to sorb contaminants.

Analysis for anthropogenic radionuclides indicated the presence only of ${ }^{239 / 240} \mathrm{Pu}$ in the sediment with the highest activity (at the top section of the core) being $0.420 \mathrm{~Bq} / \mathrm{Kg}$. Other anthropogenic radionuclides including the beta-emitter ${ }^{90} \mathrm{Sr}$ and the gamma-emitters such as ${ }^{60} \mathrm{Co}$, ${ }^{134} \mathrm{Cs}$ and ${ }^{137} \mathrm{Cs}$ were below detection limits. 


\section{REFERENCES}

Barnes, C.E. and J.K. Cochran, 1993, Uranium Geochemistry in Estuarine Sediments: Controls on Removal and Release Processes, Geochimica et Cosmochimica Acta,

Vol. 57, p. 555

Bondietti, E.A. and C.W. Francis. "Geologic Migration Potentials of Technetium-99 and Neptunium-237," Science. Vol.203, 1979, p. 1337. also appearing in PNL-SA-857, 1979.

Curtis, D.B. "Geochemical Controls on ${ }^{99} \mathrm{Tc}$ Transport and Retention," Chemical Geology. Vol.55, 1986, p. 227-231.

Di Toro, D., J. Mahoney, P. Kirchgraber, A. O'Byrne, L. Pasqale and D. Piccirilli. "Effects of Nonreversibility, Particle Concentration, and Ionic Strength on Heavy Metal Sorption, Environmental Science and Technology, 1986, Vol. 20, p. 55-61

Fuhrmann, M, R. Pietrzak, J. Neiheisel and R. Dyer. "Partitioning of Cs-137 Between Sediment and Water From the Black Sea", Chemistry and Ecology, 1992, Vol. 7, p. 3-17

Fuhrmann, M., R. Dyer and J. Neiheisel. " Adsorption of Long-lived Radionuclides on Sediment from the Kara Sea", In: Environmental Radioactivity in the Arctic and Antarctic, 1993, p. 391-393 Eds: Per Strand and E. Holm, Norwegian Radiation Protection Board, Osteras, Norway. Proceedings of the International Conference on Environmental Radioactivity in the Arctic and Antarctic, Kirkenes, Norway, August, 1993.

Gschwend, P. and S. Wu. "On the Constancy of Sediment-Water Partition Coefficients of Hydrophobic Organic Pollutants", Environmental Science and Technology, 1985, Vol. 19, No. 1, p. $90-96$

Gmelin Handbuch der Anorganischen Chemie. Technetium, 1983, Springer-Verlag.

Honeyman, B. and P. Santschi. "Metals in Aquatic Systems", Environmental Science and Technology, 1988, Vol. 22, p. 862-871.

Kotegov, S. et al, as referenced in: Wildung, R.E., K.M. McFadden and T.R. Garland, " Technetium Sources and Behavior in the Environment", Journal of Environmental Quality, 1979, Vol.8, No.2, p.156-161.

Landa, E.R., L.J. Thorvig and R.G. Gast. "Effect of Selective Dissolution, Electrolytes, Aeration and Sterilization on Technetium-99 on Soils", Journal of Environmental Quality, Vol.6, 1977, p. 1986.

Lee, S.Y. and E.A. Bondietti. "Technetium Behavior in Sulfide and Ferrous Iron Solutions," Material Research Society Symposium Proceedings. 1983, Vol.15, p. 315-321. 
McKinley, J.P. and E. Jenne. "Experimental Investigation and Review of the "Solids Concentration" Effect in Adsorption Studies", Environmental Science and Technology, 1991, Vol. 25, No. 12, p. 2082-2087

Meyer, L. M.. "Relationship Between Mineral Surfaces and Organic Carbon Concentrations in Soils and Sediments, 1994, Chemical Geology, Vol. 114, p. 347-363

Meyer, R.E., W.D. Arnold, and F.I. Case. "Valence Effects on Solubility and Sorption: The Solubility of Tc(IV) Oxides," NUREG/CR-4309, 1986, Oak Ridge National Laboratory, Oak Ridge, TN.

Mount, M., M. K. Shaeffer and D. T. Abbot, "Estimated Inventory of Radionuclides in Former Soviet Union Naval Reactors Dumped in the Kara Sea", In: Environmental Radioactivity in the Arctic and Antarctic, 1993, p. 81-87, Eds: Per Strand and E. Holm, Norwegian Radiation Protection Board, Osteras, Norway. Proceedings of the International Conference on Environmental Radioactivity in the Arctic and Antarctic, Kirkenes, Norway.

Noll, B., S. Seifert and R. Munze. "Zur Hydraluze von Technetium (IV) Perchlorsauen Lasungen, Zentralinstiut fur Kernforschung Rossendorf," ZFK-294, p. 145-150 as referenced in Meyer, 1986.

Perrier, C. and E. Segre. "Some Chemical Properties of Element 43.II," Journal of Chemical Physics, 1939, Vol. 7, No.155.

Price, N.B. and S.E. Calvert. "The Geochemistry of Iodine in Oxidized and Reduced Recent Marine Sediments", Geochimica et Cosmochimica Acta, 1973, Vol. 37, p.2149

Salter, P.R., and G.K. Jacobs, "BWIP Data Package for Reference Solubility $k_{d}$ Values," $53-$ BWI-DP-001, 1984, Rockwell Hanford Operations, Richland WA,

Voice, T., C. Rice and W. Weber. "Effects of Solids Concentration on the Sorptive Partitioning of Hydrophobic Pollutants in Aquatic Systems", Environmental Science and Technology, 1983, Vol. 17, No. 9, p. 513-518.

Wildung, R.E., K.M. McFadden and T.R. Garland, "Technetium Sources and Behavior in the Environment", Journal of Environmental Quality, 1979, Vol.8, No.2, p.156-161. 